\title{
Exchange Rate Regimes and Supply Shocks Asymmetry: the Case of the Accession Countries
}

\author{
J an Ba betski \\ Laurence Boone \\ Mathilde Maurel
}
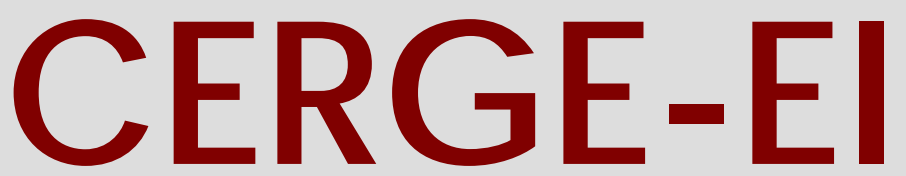

CharlesUniversity Centerfor Economic Research and Graduate Education Academy of Sciences of the Czech Republic 


\title{
Exchange Rate Regimes and Supply Shocks Asymmetry: the Case of the Accession Countries
}

\author{
Jan Babetski ${ }^{+}$, Laurence Boone ${ }^{\dagger}$, Mathilde Maurel ${ }^{\ddagger}$
}

January 2003

\begin{abstract}
This paper reviews the pros and cons of an early EU enlargement towards Central and Eastern European Countries (CEECs hereafter). Firstly, the Maastricht criteria, which cannot be literally assessed during the catching up process, but that nevertheless mirror the huge efforts undertaken in order to (i) stabilise the economies, (ii) converge towards the EU, and then (iii) participate in the EMU, are analysed. Secondly, real convergence is observed to occur at different rates, depending upon the initial conditions faced and the productivity gains realised by each country. Thirdly, computing the correlation of demand and supply shocks in a sample of Euro countries, such as Ireland, Portugal and Spain, at the time when they were entering the EU and the CEECs, gives some indication of the similarity of the business cycles and economic structures of the CEECs on the one hand, and the EU on the other. However, we argue that looking at static correlation only (averaged over the last decade) is too simplistic, as these averages will be blurred by the transition process. Using the Kalman filter, we are able to compute time varying correlation, hence differentiating between the transition and the most recent period. Our results emphasise an ongoing process of demand shocks convergence, but supply shocks divergence. Various exchange rate strategies are then discussed.
\end{abstract}

Abstrakt: Tento èlánek posuzuje pro a proti rozšíøení Evropské Unie do zemí støední a východní Evropy (Central and Eastern European Countries - CEEC - v textu). Zaprvé, jsou analyzována Maastrichtská kriteria, která nemohou být pøíliš literárnì ocenìna bìhem pøechodného procesu, ale která nicménì odráží ohromné snahy pøijaté z dùvodu (i) stabilizace ekonomiky, (ii) smìøování k EU, a (iii) úèast v EMU. Za druhé, reálná konvergence se objevuje $\mathrm{v}$ rùzných pomìrech, závisejících na vstupních podmínkách a nárùstech produktivity $\mathrm{v}$ každé zemi. Za tøetí, výpoèet korelace šokù poptávky a nabídky v CEEC a ve vybraných Evropských zemích, jako Irsko, Portugalsko a Španìlsko, v dobì, kdy vstupovaly do EU, indikuje podobnost hospodáøských cyklù a ekonomických struktur CEEC a EU. Dále uvádíme argumenty, že pohled pouze na statické korelace (prùmìry za minulé desetiletí) je pøíliš zjednodušený, protože tyto prùmìry jsou zastøeny procesem pøechodu k tržní ekonomice. Užitím Kalmanova filtru jsme schopni vypoèítat korelaci mìnící se $s$ èasem. $Z$ toho vidíme rozlišení výsledkù mezi raným a nedávným obdobím. Naše výsledky ukazují konvergenci šokù poptávky, ale divergenci šokù nabídky. Na závìr jsou diskutovány rùzné strategie smìnných kurzù.

Keywords : EU enlargement, exchange rate regimes, OCA criteria, Kalman filter

JEL Classification : E32, F30, F42

\footnotetext{
* This research was undertaken with support from the European Community's Phare ACE Program P98 1061R. The authors are very grateful to Tamim Bayoumi (IMF) who kindly provided us with valuable expertise and the computer program for supply and demand shocks decomposition. We thank Michal Kejak, Jan Kmenta, Evzen Kocenda, Daniel Munich and Jan Svejnar for comments. We also benefited from participants at three Phare ACE project workshops.

${ }^{+}$CERGE-EI, Charles University and CNRS-ROSES, University of Paris I. Email: jan.babeckij@cerge-ei.cz

† OECD. Email: laurence.boone@oecd.org

${ }^{\ddagger}$ CNRS-ROSES, University of Paris I, Centre François Simiand, and CEPR. Email: maurelm@ univ-paris1.fr
} 


\section{Introduction}

EU enlargement towards the East is unprecedented: First, the situation of the CEECs is very different from that of the previous entrants into the EU (Spain, Portugal, Greece for example): not only is the average GDP per head lower, there is also institutional underdevelopment and immaturity in Eastern financial and banking sectors ${ }^{1}$, although progress has been made in those areas, reducing the disparity between the CEECs and the EU countries. Secondly, should the CEECs enter the EU in 2004, the delay between formal candidacy and actual admission would be exceptionally short. More generally, the wide range of possible macro-economic situations, both in terms of growth and inflation, may raise questions regarding the opportunity of a common policy mix.

It is, then, an unprecedented enlargement, whose different conditions might be, at least at first glance, contradictory : Maastricht criteria are not compatible with catching-up objectives, because nominal exchange rate stability implies an inflation higher than the average of that of the best three countries, as long as countries' growth rates are higher than the European average. Catching-up is not only measured in terms of macro-economic aggregates, it has also an institutional dimension that, while harder to evaluate, might be essential. Thus, according to Jürgen Kröger and Denis Redonnet (2001): “Compliance with the Copenhagen criteria takes precedence over compliance with nominal convergence criteria, and therefore EMU participation, for at least two reasons. First, greater progress towards real and structural convergence should take place ahead of nominal convergence, even though the two can be mutually supportive. Second, only countries that are functioning market economies capable of coping with competitive pressures can be assessed for nominal convergence; that is, the Maastricht criteria must be applied to "comparable economies"."

\footnotetext{
${ }^{1}$ See Erick Berglöf and Gérard Roland (1998), Jérôme Sgard (1995a), (1995b).
} 
Copenhagen criteria are harder to assess than Maastricht criteria. Besides, they are much more likely to be affected by accession itself than macro-economic criteria (even though recent literature on OCAs has largely proved the endogenous nature of nominal and real convergence criteria, of financial and economic integration, and of the degree of symmetry of the shocks ${ }^{2}$ ). That is why our purpose here is not to review all the necessary conditions for the enlargement to be successful, but rather to focus on a subset of macro-economic criteria. When joining the EU, the CEECs will have to adopt the "acquis communautaire", part of which is the EMU, if not the euro itself, whether in the short or medium term ${ }^{3}$. Although this does not mean that Maastricht criteria are required in the meantime, it implies convergence and stability along these lines ${ }^{4}$. Moreover, nominal convergence is a necessary (although not sufficient) condition for real convergence to take place, and the very similarity in terms of GDP per head and GDP volatility can serve as an additional criterion to see whether joining the same economic area is in each country's interest. Finally, sharing the same monetary policy is not only a matter of GDP levels, but also of business cycles similarity. Assume that two countries, A (in the core, rich) and B (peripheral and poor), have the same business cycle around a trend which is completely different: they can share the same monetary policy, while the real exchange rate can adjust to changing economic circumstances and shocks, not through changes in the nominal exchange rate, but through changes in wages and prices.

This paper reviews and documents the pros and cons of the CEECs joining the EMU. Section 2 examines how the CEECs perform with regards to the traditional Maastricht criteria, as well as the evolution of their current account, and its direct impact on the exchange rate.

\footnotetext{
${ }^{2}$ See Frankel and Rose (1998).

${ }^{3}$ See Agenda 2000, Strategy for Enlargement Document, Report on the progress made by every candidate country on their way to accession, European Union Bulletin, Supplement 3/2000, p. 28 : "The Economic and Monetary Union (EMU) is an essential part of the «acquis ». It is however convenient to distinguish clearly between participation in EMU - compulsory for all member states- and participation in the euro".

${ }^{4}$ This is similar to the non EMU countries (the UK, Denmark and Sweden) presenting a "convergence
} 
Although not required for eastern candidates to be eligible, these criteria allow a distinction between two groups of countries, those where a sound macro-economic environment has already emerged, and where the process of catching up is already at work, and those who still experience large imbalances, hyperinflation, and where the convergence process is lagging. In the long run, fiscal discipline is a good thing as well, for two complementary reasons. First, controlling public expenditures should lead to a better allocation of funding; second fiscal discipline yields lower interest rates, and also helps stabilise inflation expectations. Nominal convergence has favoured real convergence in term of GDP per head, simply because economic recovery cannot occur without stabilisation. The second set of criteria is therefore that of real convergence, and section 3 again emphasises two "types" of countries which have to be clearly separated for analytical purposes: those who would benefit in terms of catching-up from anchoring their money to the euro for stabilisation purposes (Bulgaria and Romania), and those who have the option of keeping their monetary and exchange rate policy independent, because the toughest part of the stabilisation process has already been done. For these two groups the rationale behind euroization or participation in the EMU is therefore different. In Section 4, using the OCA approach as operationalised in Bayoumi and Eichengreen (1996), we try to distinguish between countries for which a common monetary policy is a useful stabilisation tool and those for which the costs would outweigh the benefits. Policy implications regarding the exchange rate strategies for EU candidate countries are drawn in the conclusion.

\section{2. "Enlarged" Maastricht criteria revisited}

According to the recent summit of Copenhagen in December 2002, the CEECs are supposed to join the EU in the very near future, in May 2004 ( 2007 for Bulgaria and Romania), which means, subsequently, EMU membership. EU admission requires candidate countries to have 
achieved "the Stability of institutions guaranteeing democracy, the rule of law, human rights, and respect for and protection of minorities; the existence of a functioning market economy, as well as the capacity to cope with competitive pressure and market forces within the Union; the ability to take on obligations of membership, including adherence to the aims of political, economic, and monetary union." The institutional Maastricht criteria were designed to facilitate the latter aims of economic and monetary union, selecting EU countries by minimising inflationary pressure in the common currency zone towards the "best practice countries", and by avoiding free riding behaviours, which would be unsustainable beyond the short term.

- Inflation should be low, within $1.5 \%$ of the average inflation rate of the three countries with the lowest rates over the past two years;

- Long-term interest rates must be within $2 \%$ of the three lowest interest rates in EU;

- Exchange rates also have to be stable, within the 15\% ERM bands for at least two years;

- Budget deficit and public debt should not be higher than 3\% and 60\% of GDP respectively, and declining for the latter.

While in the nineties the best practice was assessed on the basis of national policies, it is clear now that the benchmark can only be the European Central Bank. Furthermore, regarding transition countries, the monetary requirements have to be modified in order to make compatible the catching-up process - implying inflation rates above the EU average - and the fiscal discipline across countries aspiring to sharing a common European currency ${ }^{5}$. As a consequence they are not formally required for the EU enlargement.

Even if Maastricht criteria are not formally required, CEECs often tried to manage their currency in order to be in compliance with them. A strong argument for explaining this

\footnotetext{
${ }^{5}$ One possibility would be that the level of inflation does not exceed inflation in tradables in order to adjust
} 
compliance can be found in a recent paper by Gomulka [2001], who recalls that joining EU means subsequently participating in EMU. It is clear for the author that the benefit from joining the EU far exceeds the cost associated with fiscal discipline: it comes not only from budgetary transfers from the West, but also from the possibility of facing lower interest rates without raising uncertainty and increasing risk of speculative attacks ${ }^{6}$. Hence, bearing in mind that the institutional criteria are part of the strategy for entering the EU for some CEECs, it is worth asking to what extent monetary and fiscal policies across CEECs were, and are still now, in accordance with them.

\section{[Insert Table 1 (a), Annex 1]}

Applied to the CEECs, Maastricht criteria lead to distinguishing two subsets of countries: Romania and Bulgaria on the one hand, the rest of the CEECs on the other. For Romania, stabilisation is far from completion, with inflation mainly reflecting the monetary financing of the deficit. Prices were regulated until 1996, when liberalisation resulted in a jump in the inflation rate. For Bulgaria, the data clearly show the 1997 hyperinflation process, which ended with the implementation of a currency board.

In other countries, inflation rates are still above the levels required by the Maastricht criteria, but the trend is that of a decrease in inflation, from $28.2 \%$ in 1995 in Hungary, to an estimated $5.3 \%$ in 2002 . It is also worth noticing that while the average figure for inflation for the euro was $2.1 \%$ in 2002, and the best three EU countries averaged $1.4 \%$, the figures for the Baltic States reveal very low inflation levels by historical EU standards (3.5\% in Estonia; $1.6 \%$ in Latvia; and $0.4 \%$ in Lithuania). For the years 2000, 2001, and 2002, the CEECs 
averages are single digit, at respectively $6.6 \%, 5.6 \%$ and $3.2 \%$. Amongst the best performers, the Czech republic employed a monetary policy based on keeping the nominal exchange rate stable up to the crisis in 1997, and from then onwards moved to a policy of inflation targeting, where de facto the korona proved to be quite stable ${ }^{7}$. The three Baltic States implemented either a credible and long lasting pegging to the DM, or even a currency board in Estonia, while in Hungary or Poland, the exchange rate regimes are more flexible: Hungary adopted a fixed peg, with small adjustments every year (which take into account the inflation differentials between Hungary and the countries in the reference basket) and Poland moved from a crawling peg to a managed float in 2000).

\section{[Insert Table 1 (b-c), Annex 1]}

Interest (lending and deposit) rates are quite high, far above the level of EU countries. This reflects more the difficulties encountered in implementing a competitive and efficient banking and financial system by these countries, which have to address the persistent problem of moral hazard and adverse selection, than the high level of inflation rates. In the Czech Republic for instance, the persistence of high interest levels while inflation declined contributed to boosting commercial banks profits and to improving their capital position. In addition, once a country decides to implement a fixed exchange rate regime, and inflation and interest rates are high, interest rates in real terms are likely to fall below the European average (and even to become negative). The monetary conditions index (MCI) measures the expansiveness of interest rates; in a restructuring economy in which the hardening of the budget constraint is essential, an overly expansive policy is not desirable.

\footnotetext{
${ }^{6}$ Joining EMU would imply avoiding the difficult trade-off between, on the one hand, low interest rates but increasing financial vulnerability and high interest rates, an, $\mathrm{d}$ on the other, an increase in unemployment.

${ }^{7}$ For an overview of the evolution of monetary policy in transition economies, see Brada and Kutan (2001).
} 


\section{[Insert Table 1 (d-e), Annex 1]}

Public and debt deficits finally are rather unstable, but at levels which remain compatible with the $3 \%$ and $60 \%$ ratio of GDP criteria ${ }^{8}$. In the case of transition countries, one may fear that the low level of public debt observed at the beginning of the nineties was underestimated and could increase sharply in the following years. However the data do not support such an hypothesis: the trend was towards a continuous decrease, to $33.7 \%$ in 1998 (it stabilises around $34 \%$ over 1999 - 2002), that is, half of the EU average. The debt's decline in Hungary, from $79 \%$ in 1992 down to $57.6 \%$ in 2002 (estimate), is particularly spectacular, and it is worth noting that the Hungarian debt, as a percentage of GDP, has been akin to the EU's since as early as 1996. The evaluation of fiscal convergence in Baltic States by Kutan and Pautola-Mol (2001) emphasises similarly the impressive fiscal performance of these three transition countries by Western European standards. Halpern and Nemeyi (2001)'s opinions are much more reserved. The authors consider that the consolidation programmes required for greater transparency (in the Czech Republic, for instance) - the lack of which casts doubt on official statistics interpretation - or the problems associated with structural adjustments (in Poland, for instance), could explain a deterioration of tax revenue in the coming years. The «snowball »effect, according to which sustained growth leads to finance debt increases at lower costs, probably helped the CEECs during the '90s (as was the case with Ireland), but could harm them in the following years if a growth slowdown occurs.

\footnotetext{
${ }^{8}$ The question of the optimal level of deficit in the CEECs is controversial. Although it can be argued that public expenditures do contribute to enhanced growth, at least in the short run, we believe that this is not true for the majority of transition countries, where the soft budget constraint still holds, particularly in the state sector. Secondly the evidence for developing countries is that the level of public expenditures is negatively correlated with that of growth; see Havrylyshyn, Izvorski, and van Rooden (1998); Havrylyshyn, van Rooden (2000); and De Melo and alii (1996).
} 


\section{[Insert Table 1 (f) and Table 2, Annex 1]}

Table 2 shows that the countries that achieved stability by anchoring of their currency are later able to switch to more flexible regimes. Such is the case with the Czech Republic, Hungary, Poland, Romania and Slovakia. This suggests that the cost of loosening the option of a counter-cyclical policy is higher for middling countries, "which are in an intense process of structural change whose outcome is difficult to predict, and which might therefore need some flexibility in their real exchange rate for some time" (Gros, 2000). But for very strong countries, including Estonia, who fulfil the Maastricht criteria by means of a currency board, and for very unstable and emerging-market countries, like Romania and Bulgaria, unable to engage in counter-cyclical monetary stabilisation policies, the cost of pegging the currencies might be lower. Table 1 (f) (Annex 1) reports the average and standard deviations of exchange rates since the beginning of the transition, over two years. It can be seen that the exchange rates have stabilised, and they fluctuate inside a relatively narrow band, that becomes narrower the further the transition process proceeds.

Table 5 in Annex 1 reflects the sustainability of the current account, persistent deficits reflecting a need for increasing financing that could endanger, among other factors, the stability of the exchange rate and interest rates, hence putting at risk the macro-economic balance of the country.

\section{Real convergence criteria}

If nominal convergence is a necessary pre-requisite for economic recovery to occur, it is far from sufficient. The literature on the impact of stabilisation and of "good" policies on growth firmly establishes the link between inflation, domestic credit increases and budget deficit 
(which correspond exactly to the Maastricht criteria we looked at in the previous section), and economic performance, even if, during the early years, stabilisation might cause a significant slowdown. But what really matters for stabilisation to be sustainable, is to introduce measures aimed at liberalising the economy, such as internal and external prices liberalisation, privatisation, abolition of former state controls, and so on. De Melo and Alii (1996) proposed the first indicators of liberalisation which have been further extended by the EBRD. Relying upon those indicators, they show that while macro policy explains a significant part of the growth variance, structural reforms matter more, accounting for about $70 \%$ of the variance of growth. Hence nominal convergence is not at odds with real convergence, but it is far from sufficient.

This is why we look at real convergence, which is an ex post indicator of the success of reforms and transition towards market based economies. We present two criteria: the convergence in terms of GDP per head, and the sigma convergence, which measures the evolution of the dispersion of GDP growth rates across countries.

Figures 1 to 3 (Annex 1) distinguish three groups of countries. First, the CEECs, who display the highest GDP to German GDP per head ratio, with the more spectacular evolution for Slovenia (the ratio was slightly above $25 \%$ in 1992 and approached $40 \%$ in 2002) ; then the Baltic States, which show a higher convergence rate (which is to be expected from a lower level), the GDP per head in percentage of that of Germany being multiplied by a factor of ten over the period, up to $18 \%$ of Germany's GDP by2002. On the other hand, Romania and Bulgaria exhibit very modest convergence, being characterised by a highly unstable growth paths. The convergence path mirrors a phenomenon of real appreciation, implied by 
undervalued exchange rates at the starting date, with lower or even negative GDP growth rates, and then productivity gains taking over and yielding higher growth over the most recent period.

\section{[Insert Figures 1 to 3, Annex 1]}

Another important element is whether the examined countries tend to have similar GDP growth rates evolution. Increasing dispersion in the GDP behaviour would be at odds with a common monetary policy. This is what sigma convergence measures ${ }^{9}$ : a group of countries is said to sigma converge when the variability of GDPs per head is being reduced. There is some evidence that this is the case in our group of countries ${ }^{10}$. Between 1992 and 2002, the variability of GDP across countries decreases from $39 \%$ to $17 \%$. Moreover, if we exclude Romania and Bulgaria, the decline is even more impressive, beginning at $35 \%$ and declining to $12 \%$.

\section{[Insert Table 3, Annex 1]}

By analysing nominal and real criteria we distinguish two sets of countries, that can even be considered independently from the issue of EU accession: those that have respected a certain road for macro-economic and structural adjustment and thereby succeeded in stabilising their economy on the one hand ${ }^{11}$, and those which failed to implement such policies and still display high inflation rates, high interest rates, unstable exchange rates and large imbalances. For the latter set of countries, Bulgaria and Romania, fixing the nominal exchange rate, or even setting up a currency board, must be part of an entire stabilisation programme. The cost of non

\footnotetext{
${ }^{9}$ For a more formal definition of sigma convergence, see Boone and Maurel (1998).

10 See Kocenda (2001) for convergence of the real industrial output, among other macroeconomic fundamentals, across the CEECs.
} 
stabilising is huge, but the logic here is far from that of converging towards the Maastricht criteria. For the former, keeping in mind that EU accession requires the ability to take on membership obligations, including adherence to the aims of monetary union, the cost of strongly pegging the currencies to the euro should be assessed.

\section{OCA criteria}

Even if Maastricht criteria are not going to be applied literally to CEECs, entering the EU requires very low inflation and exchange rate variability, while the higher than EU average growth and the restructuring process itself are likely to create inflationary differentials and exchange rate variability. The latter would justify a monetary policy and exchange rate policy aimed at accommodating the adverse consequences of real appreciation and inflationary pressures $^{12}$, and would be an argument against participating in EMU in the near future; CEECs would be better off waiting until most of the restructuring process is over. A recent paper by Coricelli and Jazbec (2001) provides evidence that the real exchange rate behaviour is strongly influenced by structural reforms ${ }^{13}$, at least at the beginning of transition. Nevertheless this influence diminishes over time, and finally stabilises around the fifth or sixth year. "For several Central and Eastern European countries in the process of accession to the European Union, the dynamics of the real exchange rate can now be assimilated to that of previously acceding countries such as Spain, Portugal, and Greece, with the Harrod-Balassa-Samuelson effect playing a dominant role at later stages of transition".

\footnotetext{
${ }^{11}$ Namely the Czech and Slovak republics, Poland, Hungary, Slovenia, and the Baltic States.

${ }^{12}$ Productivity gains in the tradable sector imply inflation in the non tradable sector through the Balassa Samuelson effect.

${ }^{13}$ which are measured by the ratio of the workers employed in manufactured on the number of workers employed in services, and instrumentalized by the well known structural reform index of De Melo, Denizer and Gelb (1996) and total credit to the private sector (EBRD Transition Report, 1999).
} 
Another argument related to the above Balassa Samuelson effect is that the probability of asymmetric shocks might still be high, requiring the use of an independent monetary and exchange rate policy. But again, if we assume that the influence of asymmetric shocks imputable to restructuring is over, then the question is whether the cost of accommodating higher inflation and productivity gains by labour and price flexibility outweighs the benefit of being a member of the EU currency union (the same question was asked for Portugal, Spain and Ireland when they were candidates). In what follows, we show that the nineties were characterised by a level of supply and demand shocks symmetry (between EU and CEECs) quite comparable to the symmetry that prevailed between EU and previously acceding countries. A more worrying fact is that while demand shocks symmetry seems to increase, the asymmetry in supply shocks prevails; but this latter phenomenon may also be observed for countries such as Spain, Portugal, and Ireland.

\subsection{Methodology}

Following the literature derived from OCA theory that was used to assess the cost of EMU for "euroland countries", we answer this question by assessing the differences in business cycles between the EU and the eastern countries ${ }^{14}$. The idea is that the closer the fluctuations of the countries, the more they will benefit from a common policy response. On the other hand, if shocks are asymmetric then giving up a tool of national policy management will be costly. A measure of the similarity of business cycles across countries is the correlation of demand shocks, and its evolution since the transition process began. Furthermore, with respect to transition countries, the similarity of supply shocks should also be analysed. The former will reflect temporary shock and hence the shape of the business cycle, while the second will represent the structural side of the economy. 
For current EMU countries, the exchange rate was mainly a demand stabilisation tool. For transition countries however, foregoing the exchange rate is foregoing a tool that was used to adjust both demand and supply shocks, as exchange rate policies have often been used to help address the adverse supply shocks of the transition towards a market economy, which rendered entire sectors non competitive. They consisted sometimes of huge devaluations (see Poland) to smooth the restructuring process and the increase in unemployment. In the long run, of course, the currency should return to its equilibrium value, which implies a steady appreciation as progress in restructuring is made, liquidation of uncompetitive sectors at world market clearing prices occurs, and there are productivity gains in the newly emerging private sector.

Furthermore, it is reasonable to assume that demand shocks are very much conditioned by the nature of the monetary regime, whereas supply shocks are reflect the process of transition towards the market, as argued above. Distinguishing demand from supply shocks is therefore very important, since the former are likely to reflect an endogeneous process where the similarity of demand shocks is the very product of the alignment of CEECs monetary policy on the EU monetary policy, while the latter are informative about whether CEECs are still facing asymmetric shocks before entering the monetary union (once the convergence process has resumed). Therefore we take into account the fact that countries that share a common policy are likely to display the same (endogeneous) pattern of demand shocks as in the EU, while supply shocks are more likely to reflect productivity gains occurring only in transition countries, that is, to generate a certain level of asymmetry between EU member countries and CEECs ${ }^{15}$. Our methodology consists of two steps.

\footnotetext{
${ }^{14}$ For previous similar studies, see Boone (1997), Boone and Maurel (1999), Horvath (2001).

15 De Grauwe and Aksoy (1999, page 8) cannot distinguish supply from demand shocks on the basis that available time series are too short: "Unfortunately, this procedure requires relatively long time series. These
} 
1) Following the methodology of Bayoumi and Eichengreen (1996), demand and supply shocks are estimated with a VAR model for the accession countries, United States and the aggregate EU-15 as alternative benchmarks. Because the sample largely covers the transition period, we expect the correlation coefficients between countries to be rather weak for both types of shocks (Horvath, 2001). We pay attention to both the transition supply shock and to the fact that OCA criteria fulfilment may be endogenous from the demand $\operatorname{side}^{16}$, i.e. that demand shocks are likely to be more satisfied as monetary integration deepens, owing to the process of adherence to the EMU. Indeed, in many cases the currencies were more or less pegged to the DM.

2) In a second step, Following Boone (1997) we use time-varying estimation (Kalman filter) to compute "time-varying correlation coefficients", and expect that the path of the demand coefficients will mirror a convergence process at work. More formally, we estimate time varying $\mathrm{a}(\mathrm{t})$ and $\mathrm{b}(\mathrm{t})$ coefficients in equation (1), and analyse their evolution over time:

$$
X_{E U}-X_{C E E C S(i)}=a(t)+b(t) \cdot\left(X_{E U}-X_{U S}\right)
$$

For a convergence process to be at work, both $\mathrm{b}(\mathrm{t})$ and $\mathrm{a}(\mathrm{t})$ must tend towards zero, as this will mean that the shock $\mathrm{X}(\operatorname{CEEC}(\mathrm{i}))$ is entirely explained by the reference (EU) shock. Furthermore, the more $b(t)$ diverges from zero and tends towards one, the more important the rest of the world is (here proxied by the United States) in contributing to the shocks affecting the

are as yet unavailable for central European countries. As a result, we will rely on a procedure which does not attempt to separate demand and supply shocks".

${ }^{16}$ As argued by Frankel and Rose (1998) and Boone and Maurel (1998). In explaining the symmetry of business cycles, Frankel and Rose (1998) emphasise that a high degree of symmetry might be due to the monetary regime, which would explain the level of trade integration as well. Hence in the equation where economic co-variation is explained by trade, the latter has to be instrumented by distance. 
eastern country. ${ }^{17}$ Intuitively, for supply shocks, we would expect $b(t)$ to increase or remain stable over time as long as the transition process evolves; for demand shocks, we would expect $\mathrm{b}(\mathrm{t})$ to start from a relatively high level, and to decrease over time as the monetary integration deepens. Ultimately, this would mean that demand shocks in the candidate country and reference country are getting closer and therefore can be addressed by a common monetary policy, while supply shocks have to be addressed through internal adjustments ${ }^{18}$.

\subsection{Data}

For running the VAR model we used real GDP in national currencies and GDP deflator. Our sample consists of four developed countries (Ireland, Portugal, Spain and the United States), for whom yearly and quarterly time series are available. It covers the period $1962-2002$. Both yearly and quarterly data are seasonally adjusted by the OECD.

We add to that core sample ten EU accession countries: Bulgaria, the Czech Republic, Estonia, Hungary, Latvia, Lithuania, Poland, Romania, Slovakia and Slovenia. For those countries the data are quarterly, from 1990 up to 2002. The sources are mixed: OECD, IMF and national statistics. While OECD data are already seasonally adjusted, we had to adjust the remainder by applying the U.S. Bureau of Census' X12 procedure (the same approach as used by the OECD).

\subsection{Results}

Comparing the results based upon yearly and quarterly frequency allows the selection of "optimal lag length" for eastern countries in the VAR analysis, for whom only quarterly data are

\footnotetext{
${ }^{17}$ For details on the VAR methodology, see Bayoumi and Eichengreen (1996) and Boone and Maurel (1998); for details on the application of the Kalman filter to this analysis, see Boone (1997).

${ }^{18}$ Our methodology does not take into account the possibility that transmission mechanisms are likely to differ across current EMU countries and candidate countries. Such differences could influence the degree of
} 
available. The results in Boone (1997), who extracts demand and supply shocks for EU countries using a two-lag VAR process, are used as a benchmark. As can be seen in Annex A, eight lags deliver a similar output as two lags for yearly data. In subsequent analysis, although the marginal cost of adding a lag is high given the short time span, we will present results based upon eight lags, equivalent to two years.

This approach should be adopted with considerable caution. First, the sample sizes are small, hence complicating the task of econometrics. Second, quarterly data are very informative, but can also be noisy. Thirdly, although a deeper convergence process may be at work, it might be too recent and/or too weak to be captured by an econometric estimation. Hence, our analysis is based upon the following definitions: we consider that (i) a process of convergence is at work if $a(t)$ is constant and close to zero and $b(t)$ declines over the period; convergence is weak if (ii) either a(t) is constant but not necessarily nil, and $b(t)$ declines towards zero or (iii) b(t) shows signs of decline at least over the latest part of the sample, or has shown signs of decline but with most recent observations departing; (iv) the pattern is unclear when we observe for either $a(t)$ or $b(t)$ an erratic pattern, although the trend for $b(t)$ is downwards; and (v) there is no convergence (there is divergence) in all other cases.

Finally, assessing whether pegging the currency is a good option can be asked in absolute terms, but also in relative terms, by comparing the "optimality" of pegging for candidate and EU member countries, like Ireland, Spain and Portugal, at the time when they were entering the EU, and in the nineties. We could have chosen Greece as an alternative benchmark, but the lack of data for Greece excluded this possibility. Austria, Finland and Sweden joined the EU in 1995 (see table 6), which is too late for analysing the consequences of

symmetry of business cycles. 
their EU memberships; furthermore, we considered that in terms of GDP per head, CEECs are more similar to Mediterranean countries than to Scandinavian ones.

Results are reported in Annex A for Ireland, Portugal and Spain and Annex B for CEECs. Overall, it turns out that distinguishing some clear pattern is not such a difficult task despite the short period of time. Regarding supply shocks, one can observe that Portugal and Spain do converge towards EU prior to their entry into EU in 1986, while the contrary holds for the majority of CEECs, for whom the evolution of $a(t)$ and $b(t)$ denotes clearly a pattern of divergence. This striking feature of the transition towards the EU market in the nineties has to be mitigated by two remarks. Firstly, the coefficient $b(t)$ averaged over a ten years period before the Spanish and Portuguese EU entry ${ }^{19}$ is higher than its Eastern counterpart ${ }^{20}$. Hungarian supply shocks for instance are linked to EU ones by a factor of 0.39 , while the same factor ranges from 0.37 (Portugal) to 0.5 (Spain) for EU former candidates. Furthermore, after having converged up to the date of their EU memberships, both Portugal and Spain diverge from the EU pattern of supply shocks, which suggests that the criteria of symmetry do not necessarily have to be met for a proper functioning of the EU monetary policy co-ordination. One argument concerning this latter result is that asymmetry is not necessarily bad news in as much as it enables participating states to diversify idiosyncratic risks. In other words, region specific productivity shocks are beneficial to union-wide income, because all other regions may hold claims on that $\operatorname{part}^{21}$. Moreover, within EMU, a deeper level of asset portfolio diversification can be achieved thanks to capital market integration.

\footnotetext{
${ }^{19}$ And only over two years for Ireland, which entered the EU in 1973.

${ }^{20}$ See table B and subscripts 1 to 4 which allow to compare table A (Annex A) and Table B itself.

${ }^{21}$ See Asdrubali Sorensen and Yosha (1996), Mélitz and Zumer (2000), and McKinnon (2002).
} 
CEECs' convergence over the last period is more clear-cut from the demand side than from the supply side. This is not surprising, given that the shock of transition towards a market economy affected transition countries but obviously not EU countries. Therefore, if supply shocks convergence is rather loose, demand shocks are increasingly synchronised with EU demand shocks. This has to be linked to the strategy of accession undertaken by many CEECs, who have been able to achieve some measure of convergence between the evolution of their money stock and that of Germany, as shown in Brada and Kutan (2001).

Overall, countries achieve higher level of convergence when they commit towards fixing their currencies: both supply and demand shocks (only demand shocks) are converging towards EU shocks in Estonia (in Latvia). For the latter Kutan et Pautola-Mol (2001) measure cyclical sensitivity of State's budget to business cycle, and conclude that " evidence on the cyclical sensitivity of the Baltic States suggests that the Stability and Growth Pact [...] would offer enough room for automatic fiscal stabilizers in Estonia and Latvia “.

\subsection{Exchange rate strategies for EU candidate countries}

Which exchange rate regimes are desirable for countries wanting to join the EU in the mean term? Two of them are clearly incompatible with the admission agenda ${ }^{22}$, which implies notably that the exchange rate policy must be considered as a matter of common interest, and that, in the relatively short term, the newcomer country must apply the ERM2 functioning rules. More concretely exchange rates must not depart from central parity and their volatility must not exceed a $15 \%$ fluctuation band for at least two years ${ }^{23}$. Hence crawling pegs, and pegs against

\footnotetext{
${ }^{22}$ This agenda consists of four steps: “ (1) prior to accession no formal restriction on the choice of the exchange rate regime; (2) upon accession, new Member states must adopt an exchange rate policy as a matter of common interest (Article 124); (3) after accession, although not necessarily immediately, join the EMR2; (4) after application of the procedure in Article 121, the adoption of the rate at which the euro will be substituted for the currency of the Member State and start preparations to introduce the euro."

${ }^{23}$ Hungary's regime - horizontal band with $15 \%$ fluctuation bands - is compatible with ERM2.
} 
anchors other than the euro, cannot be allowed. Other exchange rate regimes are compatible with the idea of ERM2 participation, conditioned to their credibility and to their ability not to put the catching up process of the CEECs at risk :

- Currency boards (and unilateral « euroization ») are possible as long as fiscal discipline is assured and prices and wages are flexible enough so as to maintain the inflation differential (resulting from the growth differential) below a critical level that would endanger the country competitiveness; and also as long as the chosen peg is the euro (as is the case in Estonia and Lithuania, but not in Latvia, where the anchor is the SDR).

- The Irish example shows that a fixed nominal exchange rate does not curtail growth (one might even rather say the contrary). It must be noted that in this strategy the choice of the right conversion rate upon accession into the monetary union is essential, particularly when candidate countries have higher growth potentials than other member countries. An initial underestimation allows in fact a later real exchange rate appreciation, that in turn facilitates the absorption of the asymmetric supply shocks that were exposed in the preceding section. George M. von Furstenberg (2002) shows that "Balassa-Samuelson effects provide little reason for small countries to shun monetary union while they are catching up through fast MFP (Multifactor Productivity) growth to the slowergrowing countries at its core unless their remaining catch-up potential is very large". In other words, the inflation induced by the Balassa-Samuelson effect (that is, a price increase not proportional to the productivity gains because of the existence of a sector of non tradable goods) exceeds a critical percentage if the growth differential is high and sustainable. It is also unlikely to be higher among nations than among regions: Teolis et von Furstenberg (1993, pp. 259-261) 
show that when Mexico fixed its exchange rate in 1988, the volatility of the real exchange rate between Mexico and the United States did not exceed the one prevailing between the cities of Chicago and Los Angeles.

- Managed float, or full float, are also feasible options - five accession countries, Czech Republic, Poland, Romania, Slovakia, and Slovenia, currently operate under managed float - but practice shows that they have either inflation targeting, or monetary aggregates targeting policies. Those latter policies are characterised by P. B. Kenen (2002, page 113) as being "the last expensive and most sensible way to confer credibility on monetary policy".

As shown in the previous section, the Czech and Slovenian cases are interesting because, while supply shocks are clearly divergent, demand is increasingly explained by European demand shocks ${ }^{24}$. The alignment of exchange and monetary policies on Germany ${ }^{25}$, or on a wider scale on the EU, could be at the origin of this convergence process. Concerning supply shocks, which correspond to the more structural side of the economy, the transition process itself, that is convergence of the GDP per head towards the European level, consists in productivity shocks occurring only in the East. So there cannot be (and it is not desirable that there should be) supply shocks convergence, as long as the catching-up of the GDP per head and productivity levels is not achieved. If this catch-up potential is very high - and as a result if the probability of asymmetric supply shocks remains high - and if prices are not flexible enough, then the definitive fixing of the exchange rate might not be desirable. In this case, simply joining the ERM2 is the best strategy, because it gives countries greater latitude for absorbing asymmetric supply shocks, it formally prepares them for the later stage of adopting

\footnotetext{
${ }^{24}$ Demand shocks are temporary with no long run effect on output and prices.

${ }^{25}$ The adoption of fixed exchange rate regimes and the anchoring on German monetary aggregates indicators as shown by Brada and Kutan ( 2001 ).
} 
the euro, and it corresponds to an explicit agenda to which all different parties involved agree upon. For Jürgen Kröger and Denis Redonnet (2001): “ERM2 could provide the framework for managing a flexible exchange rate, allowing for successful catching-up while maintaining a clear orientation towards nominal convergence - and the ultimate adoption of the euro". Exchange rates are increasingly compatible with ERM2 functioning rules : Table 1 (f) shows that nominal exchange rate volatility computed over two years is decreasing on the one hand, and fluctuates around its mean (over the same period) inside a $15 \%$ band. If the conditions ${ }^{26}$ for a credible Currency Board (or a unilateral "euroization") are met, fixing the nominal exchange rate is even better because it shows that the candidate country is able to directly participate in the EMU during its catching up phase ${ }^{27}$. Another advantage of this strategy is that it enhances the credibility of EU membership candidate countries, by showing that they are willing to assume the associated costs, and by providing incentives for EMU member countries to improve their engagements ${ }^{28}$.

\section{Conclusion}

Institutional criteria are at the moment unevenly satisfied by the CEECs. But those criteria are not formally required for them to enter the EU. The reason is that the current level of inflation

\footnotetext{
${ }^{26}$ These extremely tight conditions are the reason why currency boards are introduced only in exceptional situations : Bulgaria set one up in '97 in order to control inflation. Unilateral "euroization" corresponds also to extreme situations, like the one in Montenegro : DM, on November the $2^{\text {nd }} 1999$ (see Duchêne and Alii (2000)).

${ }^{27}$ Because it can absorb asymmetric shocks due to price and wage flexibility. Babetski (2002) shows that (i) wages are more flexible in the CEECs than in western European countries; (ii) wage flexibility explains in the Granger sense the exchange rate fluctuations. Countries with more flexible labour markets adopt less flexible exchange rate regimes. Data does not allow testing for reversed causality, but it can be conjectured that adoption of the euro would mean greater flexibility in the labour market.

${ }^{28}$ In this respect, the artificial distinction between currency boards and unilateral « euroization » shows that the decision of EU enlargement has an essential political dimension. Some pretend that while the former are compatible with the EU Treaty, the latter "does not respect the principles of EMU accession negotiations, does not respect the economic rationale of the Treaty and of accession. Finally the euro can become a given country's currency only when the Council takes the decision in keeping with the Treaty procedures." Adopting
} 
partly reflects the transition process, and as long as the rate of growth in those countries is expected to be higher than in EU countries, keeping inflation at low levels, and at the same time fixing nominal exchange rates, simply makes no sense. The catching up process implies that CEECs can expect a 5 percent growth differential with current members, to be associated with a 2 percent inflation differential. For Daniel Gros, this inflation differential can reach 3 and even 4 percent.

Secondly, focusing on the similarity of business cycles and economic structures provides some encouraging signs of convergence, although a great deal of progress could be made in this respect. Nevertheless, even if the evidence that some of the CEECs are subject to shocks similar to the German or EU ones is rather weak, especially for the supply side, one should recall that the pattern of convergence was quite loose when Spain or Portugal were candidates $^{29}$. Hence, the criteria of business cycle convergence should not be overemphasised.

Supply shocks are not converging, which might be due to the Balassa-Samuelson effect. The effect has been found to be especially relevant when an open economy not depending on primary resources is growing fast by changing industrial structure and export composition (Ito, Isard and Symansky, 1999, p. 126), which is exactly the case with CEECs. But the absence of supply convergence is not necessarily bad from the point of view of EMU memberships. Emerging countries, often unable to engage in counter cyclical policy ${ }^{30}$, by fixing nominal exchange rates, have simply to let productivity gains translate into inflation differentials endogenously. The latter, which are equilibrating and consistent with international

the opposite position, Gros ( 2000) pleads for "euroisation from the Atlantic to the Urals".

${ }^{29}$ Their business cycles synchronism with EU does not turn out to be higher over the last decade.

${ }^{30}$ They de facto have followed the German Central Bank policy. 
competitiveness $^{31}$, are better than policy-induced differences in inflation rates that imperil the credibility of any exchange rate regimes, whatever fix or floating. For Von Furstenberg (2002, page 17): "Both the empirical evidence and theory suggest that differences in excess of 4 percentage points of individual member countries' annual inflation rates from the GDPweighted average inflation rate for all such countries are unlikely. Furthermore, these differences tend to diminish over time and generally are smaller than the differences observed prior to the credible fixing of exchange rates in the run-up to monetary union."

Demand shocks convergence is more clear-cut. This is in line with Brada and Kutan (2001), who show that CEECs were able to mimic ECB policies regarding the growth of their money base (allowing us to interpret the inflation differential as simply reflecting the BalassaSamuelson effect and the process of convergence itself). As a result, giving up monetary policy independence will not be so costly at the time of EU entry. It has been shown, ${ }^{32}$ furthermore, that fiscal policy was able to smooth business cycles, within the limits imposed by the Stability Pact and Maastricht criteria.

This paper reviewed and applied the classical OCA criteria to CEECs, which qualify for imminent EU entry, as soon as 2004, as decided in Brussels and Copenhagen. But it does not consider the institutional aspects of that enlargement, which could make it much more successful. What is worrying is that the current EU members have not shown (at least up to now) a strong enough intent to implement the necessary reforms to the EU budget and institutional operations - yet a date has been set and there are great expectations on the side of the CEECs. For the enlargement to be a complete success, conditions ensuring a more rapid convergence of the CEECs need to be put in place. This will not only benefit those countries,

\footnotetext{
${ }^{31}$ As argued quite convincingly in von Furstenberg (2002).
} 
but also alleviate the implied burden for the existing EU members, allowing both sides to reap the full benefit of this experience.

${ }^{32}$ For the three Baltic States, see Kutan et Pautola-Mol (2001). 


\section{References}

Asdrubali, Pierfederico, Sorensen, Bent E. and Yosha Oved, 1996, "Channels of Interstate Risk Sharing: United States 1963-1990”, Quarterly Journal of Economics, pp. 1081-1110.

Babetski, Jan. 2002. "Wage Adjustments Under Various Exchange Rate Regimes: Evidence from EU Accession Countries." CERGE-EI, Mimeo.

Bayoumi, Tamim and Eichengreen, Barry. 1996. "Operationalizing the Theory of Optimum Currency Areas." CEPR Discussion Paper $\mathrm{n}^{\circ} 1484$.

Bchir, Mohamed Heidi and Maurel, Mathilde. 2001. "Impacts économiques et sociaux de l'élargissement pour l'Union européenne et la France (Economic and social consequences of enlargement for the European Union and France)." Rapport pour le parlement. Paris.

Berglöf, Erik and Roland, Gérard. 1998. "Soft Budget Constraints and Banking in Transition Economies ". Journal of Comparative Economies, Vol. 26, 18-40.

Boone, Laurence. 1997. "Symmetry and Asymmetry of Supply and Demand Shocks in the European Union." CEPII Document du Travail (CEPII Working Paper). No 03. Paris.

Boone, Laurence. 1997. "Symétrie des chocs en Union européenne: une analyse dynamique (Symmetry of shocks in the European Union: a dynamic analysis)." L'Economie Internationale. N 70, 2e trimestre. Paris.

Boone, Laurence and Maurel, Mathilde. 1999 a, "L'ancrage de l'Europe centrale et orientale à l'Union européenne (Targeting of the Central and Eastern European Countries to the European Union)". Revue économique, Vol. $50, \mathrm{n}^{\circ} 6$.

Boone, Laurence and Maurel, Mathilde. 1999 b, "An Optimal Currency Area Perspective of the EU Enlargement to the CEECs." CEPR Discussion Paper, $\mathrm{n}^{\circ} 2119$.

Boone, Laurence and Maurel, Mathilde. 1998. "Economic Convergence of the CEECs with the EU." CEPR Discussion Paper, $\mathrm{n}^{\circ} 2018$.

Brada, Josef C. and Kutan, Ali M. 2001. "The Convergence of Monetary Policy between Candidate Countries and the European Union." ZEI (Center of European Integration Studies) Working Paper, B07, Bonn.

Coricelli, Fabrizio and Jazbec, Bostjan. 2001. "Real Exchange Rate Dynamics in Transition Economies." CEPR Discussion Paper, $\mathrm{n}^{\circ} 2869$.

De Melo, Martha, Denitzer Cevdet and Alan Gelb. 1996. "From Plan to Market." Policy Research Working Paper, $\mathrm{n}^{\circ} 1564$.

Duchêne, Gérard; Gros, Daniel; Hager, W; Najman, Boris and Schobert, F. 2000. "Notes on the Economy of Montenegro", CEPS Working Document $N^{\circ} 142$, Brussels, 47 pages.

EBRD. Transition Report. Various issues.

Frankel, Jeffrey and Romer, David. 1999. "Does Trade Cause Growth?" The American Economic Review, 89(3), June, pp.379-99.

Frankel, Jeffrey and Rose, Andrew. 1998. "The Endogeneity of the Optimum Currency Area Criteria." Economic Journal, 108(449), July, pp.1009-25.

von Furstenberg, George M. 2002. "Market Pressures For International Currency Consolidation: Insurance Aspects of Monetary Union." AFA/NAEFA Session on Global Financial Infrastructure, Atlanta, Jan. 4, 2002.

Gomulka, Stanislas, 2001, "Policy Challenges Within the (Enlarged) European Union: How to foster Economic Convergence?", paper presented at the East-West Conference "Convergence and Divergence in Europe", Vienna.

Gros, Daniel. 2000. "How Fit Are the Candidates for EMU?" World Economy, 23(10), November, pp.1367-77.

Halpern, László and Neményi, Judit. 2001. "Fiscal Foundation of Convergence to European Union in Pre-Accession Transition Countries", Paper presented at the conference on "How to Pave the Road to E(M)U: The Monetary Side of the Enlargement Process (and its Fiscal Support)" organized by the Deutsche Bundesbank, the National Bank of Hungary and the Center for Financial Studies at Johann Wolfgang Goethe-Universität in Frankfurt, Eltville.

Havrylyshyn, Oleh, Ivailo Izvorski, and van Rooden, Ron. 1998. "Recovery and Growth in Transition Economies 1990-97: A Stylized Regression Analysis.” IMF Working Paper WP/98/141. 
Havrylyshyn, Oleh and van Rooden, Ron. 2000. "Institutions matter in Transition, but so do Policies." IMF Working Paper WP/00/70.

Horvath, Julius. 2001. "Optimum Currency Area Theory and Correlation of Shocks between the Accession-Candidate Countries and the EMU." ACE Phare Project P981061R. http://econserv2.bess.tcd.ie/fidrmucj/ace/index.html. Unpublished manuscript.

Ito, Takatoshi; Isard, Peter and Symansky, Steven. 1999. "Economic Growth and Real Exchange Rate: An Overview of the Balassa-Samuelson Hypothesis in Asia." In: Changes in Exchange Rates in Rapidly Developing Countries: Theory, Practice, and Policy Issues (T. Ito and A.O. Krueger, Eds.) Chicago: Univ. of Chicago Press, 109-128.

Kocenda, Evzen. 2001. "Macroeconomic Convergence in Transition Countries". Journal of Comparative Economics. Vol. 29, No 1, 1-23, March.

Kröger Jürgen and Denis Redonnet. 2001. "Exchange Rate Regimes and Economic Integration: The Case of the Accession Countries", in: CESIfo-Forum 2(2), S.6-13.

Kutan, Ali M. and Pautola-Mol, Niina. 2001. "Integration of the Baltic States into the EU and Institutions of Fiscal Convergence: A Critical Evaluation of Key Issues and Empirical Evidence." ZEI (Center of European Integration Studies) Working Paper, B10, Bonn.

McKinnon, Ronald. 2002. "Optimum Currency Areas and the European Experience", Economics of Transition, Volume $10, \mathrm{n}^{\circ} 2$, pp.343-364.

Melitz, Jacques, and Frédéric Zumer, 1999, "Interregional and International Risk-Sharing and Lessons for EMU", Carnegie Rochester Conference Series on Public Policy, 51(0), pp. 149-88.

Sgard, Jérôme. 1995(a). "Recapitalisations bancaires et aléa moral en Hongrie et en Pologne (Bank Recapitalizations and Moral Hazard in Hungary and Poland)." Revue Economique. 46(2), March, pp.481-500.

Sgard, Jérôme. 1995(b). "Le financement de la transition en Europe centrale et balkanique (Financing Transition in Central Europe and the Balkans)". Economie Internationale, 62.

Teolis, David P. and von Furstenberg, George M. 1993. "Reducing Real Exchange Rate Variability and Drift: Mexico on the Way to North American Monetary Union?" North American Journal of Economics and Finance 4(2), Fall: 253-269. 


\section{Annex 1}

\section{Table 1. Maastricht criteria applied to the CEECs}

a) Inflation rate ${ }^{1} \%$ change, annual averages)

\begin{tabular}{|c|c|c|c|c|c|c|c|c|c|c|c|c|c|}
\hline & 1990 & 1991 & 1992 & 1993 & 1994 & 1995 & 1996 & 1997 & 1998 & 1999 & 2000 & 2001 & 2002 \\
\hline Bulgaria & 26.3 & 414.4 & 91.3 & 72.9 & 95.9 & 62.2 & 121.6 & 1058.4 & 18.7 & 2.6 & 10.3 & 7.4 & 5.8 \\
\hline Czech Rep. & 9.7 & 52.0 & 11.1 & 20.8 & 9.9 & 9.1 & 8.9 & 8.4 & 10.7 & 2.1 & 3.9 & 4.7 & 2.2 \\
\hline Hungary & 39.2 & 34.8 & 23.2 & 22.5 & 18.9 & 28.3 & 23.6 & 18.3 & 14.1 & 10.0 & 9.8 & 9.2 & 5.3 \\
\hline Poland & 553.6 & 76.8 & 45.3 & 36.9 & 33.3 & 28.0 & 19.8 & 15.1 & 11.7 & 7.3 & 10.1 & 5.5 & 2.2 \\
\hline Romania & 5.1 & 170.2 & 210.4 & 256.1 & 136.8 & 32.3 & 38.8 & 154.8 & 59.1 & 45.8 & 45.7 & 34.5 & 23.0 \\
\hline Slovakia & 10.8 & 61.2 & 10.0 & 23.2 & 13.4 & 10.0 & 5.8 & 6.1 & 6.7 & 10.5 & 12.0 & 7.1 & 3.3 \\
\hline Slovenia & 551.6 & 115.0 & 207.3 & 32.9 & 21.0 & 13.5 & 9.9 & 8.4 & 7.9 & 6.1 & 8.9 & 8.4 & 7.4 \\
\hline Estonia & 23.1 & 211.0 & 1077.7 & 89.8 & 47.6 & 29.0 & 23.0 & 11.2 & 8.2 & 3.3 & 4.0 & 5.8 & 3.5 \\
\hline Latvia & 10.5 & 172 & 951 & 109 & 35.9 & 25.0 & 17.6 & 8.6 & 4.5 & 2.4 & 2.7 & 2.5 & 1.6 \\
\hline Lithuania & 8.4 & 225 & 1021 & 410 & 72.2 & 39.6 & 24.6 & 8.9 & 5.1 & 0.8 & 1.0 & 1.3 & 0.4 \\
\hline $\begin{array}{l}\text { CEECs average } \\
\text { excl. Bulgaria } \\
\text { and Romania }\end{array}$ & 151 & 119 & 418 & 93.1 & 31.5 & 22.8 & 16.7 & 10.6 & 8.6 & 5.3 & 6.6 & 5.6 & 3.2 \\
\hline $\begin{array}{l}\text { Euro area } \\
\text { average }\end{array}$ & 4.6 & 4.1 & 4.6 & 3.9 & 3.2 & 3.0 & 2.5 & 1.9 & 1.4 & 1.2 & 2.4 & 2.7 & 2.1 \\
\hline EU average & 5.1 & 4.7 & 4.5 & 3.7 & 2.9 & 2.9 & 2.5 & 1.8 & 1.4 & 1.2 & 2.1 & 2.5 & 2.0 \\
\hline "3 best EU" av. ${ }^{2}$ & 4.3 & 4.1 & 4.4 & 3.5 & 2.6 & 2.2 & 1.9 & 1.7 & 1.1 & 0.8 & 1.7 & 2.1 & 1.4 \\
\hline
\end{tabular}

Notes: $\quad 1$ Percentage change in consumer price index in local currency (period average), over previous year.

2 Three "best performing EU countries" with lowest inflation in 2002 are United Kingdom, Germany and Austria

Sources: The Economist Intelligence Unit Country Data, 2002; EBRD Transition Report, 2001; authors' computations 
Table 1. (continued) Maastricht criteria applied to the CEECs

b) Deposit interest rate (\% per annum)

\begin{tabular}{|c|c|c|c|c|c|c|c|c|c|c|c|c|c|}
\hline & 1990 & 1991 & 1992 & 1993 & 1994 & 1995 & 1996 & 1997 & 1998 & 1999 & 2000 & 2001 & 2002 \\
\hline Bulgaria & n.a. & 39.5 & 45.0 & 42.6 & 51.1 & 35.9 & 74.7 & 46.8 & 3.0 & 3.2 & 3.1 & 2.9 & 2.8 \\
\hline Czech Rep. & n.a. & n.a. & n.a. & 7.0 & 7.1 & 7.0 & 6.8 & 7.7 & 8.1 & 4.5 & 3.4 & 3.0 & 2.8 \\
\hline Hungary & 24.7 & 30.4 & 24.4 & 15.7 & 20.3 & 26.1 & 22.2 & 18.5 & 16.2 & 13.3 & 9.6 & 9.3 & 7.4 \\
\hline Poland & 41.7 & 53.5 & 37.8 & 36.7 & 33.4 & 26.8 & 20.0 & 19.4 & 18.2 & 11.2 & 14.2 & 11.8 & 6.0 \\
\hline Romania & n.a. & n.a. & n.a. & 42.5 & 49.5 & 37.9 & 41.5 & 57.2 & 44.5 & 49.1 & 33.0 & 26.7 & 19.6 \\
\hline Slovakia & n.a. & n.a. & n.a. & 8.0 & 9.3 & 9.0 & 9.3 & 13.4 & 16.3 & 14.4 & 8.4 & 6.5 & 6.1 \\
\hline Slovenia & n.a. & 682.5 & 153.0 & 33.0 & 28.1 & 15.4 & 15.1 & 13.2 & 10.5 & 7.2 & 10.1 & 9.8 & 6.6 \\
\hline Estonia & n.a. & n.a. & n.a. & 15.9 & 11.5 & 8.7 & 6.1 & 6.2 & 8.1 & 4.2 & 3.8 & 4.0 & 3.0 \\
\hline Latvia & 328.9 & 662.5 & n.a. & 34.8 & 31.7 & 14.8 & 11.7 & 5.9 & 5.3 & 5.0 & 4.4 & 5.2 & 3.5 \\
\hline Lithuania & n.a. & n.a. & n.a. & 88.3 & 48.4 & 20.1 & 14.0 & 7.9 & 6.0 & 4.9 & 3.9 & 3.0 & 1.7 \\
\hline$\overline{\text { CEECs average }}$ & 132 & 294 & 65.1 & 32.5 & 29.0 & 20.2 & 22.1 & 19.6 & 13.6 & 11.7 & 9.4 & 8.2 & 6.0 \\
\hline "3 best EU" av. 1 & 8.8 & 7.7 & 6.8 & 3.7 & 2.4 & 2.6 & 1.9 & 2.0 & 2.3 & 1.4 & 1.7 & 1.4 & 1.0 \\
\hline $\begin{array}{l}\text { Euro area } \\
\text { average }\end{array}$ & 7.9 & 8.1 & 8.1 & 7.0 & 5.8 & 5.5 & 4.4 & 3.6 & 3.4 & 2.6 & 3.0 & 2.9 & 2.3 \\
\hline EU-15 average & 8.4 & 8.1 & 8.0 & 6.7 & 5.5 & 5.3 & 4.1 & 3.5 & 3.3 & 2.5 & 3.0 & 2.8 & 2.2 \\
\hline
\end{tabular}

Note: $\quad 1$ In 2002: Ireland, United Kingdom and Finland

Sources: The Economist Intelligence Unit Country Data, 2002; EBRD Transition Report, 2001; authors' computations

c) Lending interest rate $(\%$ per annum)

\begin{tabular}{|c|c|c|c|c|c|c|c|c|c|c|c|c|c|}
\hline & 1990 & 1991 & 1992 & 1993 & 1994 & 1995 & 1996 & 1997 & 1998 & 1999 & 2000 & 2001 & 2002 \\
\hline Bulgaria & n.a. & 48.4 & 56.7 & 58.3 & 72.6 & 59.0 & 123.5 & 84.0 & 13.3 & 12.8 & 11.5 & 11.1 & 9.4 \\
\hline Czech Rep. & n.a. & n.a. & n.a. & 14.1 & 13.1 & 12.8 & 12.5 & 13.2 & 12.8 & 8.7 & 7.2 & 7.1 & 5.6 \\
\hline Hungary & 28.8 & 35.1 & 33.0 & 25.4 & 27.4 & 32.6 & 27.3 & 21.8 & 19.3 & 16.3 & 12.6 & 12.1 & 10.2 \\
\hline Poland & 504.2 & 54.6 & 39.0 & 35.3 & 32.8 & 33.5 & 26.1 & 25.0 & 24.5 & 17.0 & 20.0 & 18.4 & 12.0 \\
\hline Romania & n.a. & n.a. & n.a. & 86.4 & 61.8 & 47.3 & 51.3 & 67.5 & 55.1 & 61.2 & 46.2 & 38.8 & 28.5 \\
\hline Slovakia & n.a. & n.a. & n.a. & 14.4 & 14.6 & 16.9 & 13.9 & 18.7 & 21.2 & 21.1 & 14.9 & 11.2 & 10.5 \\
\hline Slovenia & n.a. & 824.6 & 195.1 & 48.6 & 38.9 & 23.4 & 22.6 & 20.0 & 16.1 & 12.4 & 15.8 & 15.0 & 12.4 \\
\hline Estonia & n.a. & n.a. & 32.6 & 33.7 & 24.7 & 19.0 & 14.9 & 11.8 & 15.1 & 11.1 & 7.4 & 7.8 & 7.5 \\
\hline Latvia & n.a. & n.a. & n.a. & 86.4 & 55.9 & 34.6 & 25.8 & 15.3 & 14.3 & 14.2 & 11.9 & 11.2 & 10.0 \\
\hline Lithuania & n.a. & n.a. & n.a. & 91.8 & 62.3 & 27.1 & 21.6 & 14.4 & 12.2 & 13.1 & 12.1 & 9.6 & 7.0 \\
\hline CEECs average & 267 & 241 & 71.3 & 49.4 & 40.4 & 30.6 & 34.0 & 29.2 & 20.4 & 18.8 & 16.0 & 14.2 & 11.3 \\
\hline "3 best EU" av. ${ }^{1}$ & 14.2 & 12.4 & 11.3 & 9.5 & 7.8 & 7.9 & 6.8 & 6.5 & 5.9 & 4.3 & 5.3 & 4.7 & 3.9 \\
\hline $\begin{array}{l}\text { Euro area } \\
\text { average }\end{array}$ & 14.4 & 14.7 & 14.7 & 13.0 & 10.9 & 10.4 & 9.2 & 8.0 & 7.6 & 6.1 & 7.1 & 6.9 & 5.9 \\
\hline EU-15 average & 14.6 & 14.3 & 14.0 & 12.3 & 10.5 & 10.2 & 8.8 & 7.9 & 7.4 & 6.1 & 7.0 & 6.7 & 5.8 \\
\hline
\end{tabular}

Note: $\quad 1$ In 2002: United Kingdom, Spain and the Netherlands

Sources: The Economist Intelligence Unit Country Data, 2002; EBRD Transition Report, 2001; authors' computations 
Table 1. (continued) Maastricht criteria applied to the CEECs

d) Budget balance (\% GDP)

\begin{tabular}{|c|c|c|c|c|c|c|c|c|c|c|c|c|c|}
\hline & 1990 & 1991 & 1992 & 1993 & 1994 & 1995 & 1996 & 1997 & 1998 & 1999 & 2000 & 2001 & 2002 \\
\hline Bulgaria & $-8,1$ & $-4,5$ & -5.6 & -10.9 & -5.7 & -5.6 & -10.4 & -3.0 & 1.0 & -0.9 & -1.0 & -0.9 & -0.8 \\
\hline Czech Rep. & $-0,2$ & -1.9 & -0.1 & 0.1 & 0.9 & 0.5 & -0.1 & -0.9 & -1.6 & -2.3 & -2.3 & -3.1 & -6.1 \\
\hline Hungary & 0.5 & -2.9 & -6.1 & -6.0 & -7.5 & 1.1 & -1.6 & -1.2 & -6.5 & -3.2 & -3.5 & -5.2 & -6.5 \\
\hline Poland & 0.4 & -3.8 & -6.0 & -2.8 & -2.8 & -2.4 & -2.4 & -1.3 & -2.4 & -2.0 & -2.2 & -4.5 & -5.3 \\
\hline Romania & -0.4 & -1.9 & -4.4 & -1.7 & -4.2 & -4.1 & -4.9 & -3.6 & -2.8 & -2.5 & -3.6 & -3.1 & -2.9 \\
\hline Slovakia & n.a. & n.a. & $-11,9$ & $-6,0$ & -1.2 & 0.4 & -1.2 & -4.8 & -4.7 & -3.4 & -3.9 & -4.4 & -6.2 \\
\hline Slovenia & n.a. & 2,6 & 1.2 & 0.9 & 0.0 & 0.0 & 0.3 & -1.2 & -0.8 & -0.6 & -1.4 & -1.4 & -3.0 \\
\hline Estonia & n.a. & n.a. & -0.4 & -0.7 & 1.3 & -1.3 & -1.9 & 2.2 & -0.3 & -4.6 & -1.0 & 0.5 & 1.1 \\
\hline Latvia & n.a. & n.a. & 0.8 & 0.6 & -4.1 & -3.1 & -1.4 & 1.2 & 0.1 & -4.0 & -2.8 & -1.8 & -1.8 \\
\hline$\underline{\text { Lithuania }}$ & n.a. & n.a. & n.a. & -5.3 & -4.8 & -4.5 & -4.5 & -1.8 & -5.9 & -8.5 & -2.8 & -1.9 & -1.8 \\
\hline CEECs average & 0.2 & -2.6 & -2.6 & -2.9 & -2.8 & -1.9 & -2.8 & -1.4 & -2.4 & -3.2 & -2.5 & -2.6 & -3.3 \\
\hline Euro area average & -4.7 & -5.0 & -5.1 & -5.8 & -5.1 & -5.0 & -4.3 & -2.6 & -2.2 & -1.3 & 0.2 & -1.4 & -2.2 \\
\hline EU average & -3.9 & -4.6 & -5.3 & -6.2 & -5.4 & -5.1 & -4.2 & -2.5 & -1.6 & -0.7 & 0.6 & -0.8 & -1.8 \\
\hline
\end{tabular}

Sources: The Economist Intelligence Unit Country Data, 2002; EBRD Transition Report, 2001; authors' computations

e) Public debt*** (\% GDP)

\begin{tabular}{lccccccccccccccc}
\hline & 1990 & 1991 & 1992 & 1993 & 1994 & 1995 & 1996 & 1997 & 1998 & 1999 & 2000 & 2001 & 2002 \\
\hline Bulgaria & n.a. & n.a. & 158,7 & 150.1 & 169.0 & 114.7 & 300.5 & 103.0 & 79.8 & 84.9 & 77.1 & 70.2 & 66.0 \\
Czech Rep. & n.a. & n.a. & n.a. & 18,8 & 17.6 & 15,3 & 13.7 & 13.5 & 13.7 & 15.0 & 18.8 & 23.0 & 30.6 \\
Hungary & n.a. & 74.6 & 79.0 & 90.4 & 88.2 & 86.4 & 72.8 & 63.9 & 62.3 & 61.2 & 55.6 & 54.1 & 57.6 \\
Poland & n.a. & n.a. & 147,3 & 88,7 & 72.4 & 54.3 & 47.9 & 46.9 & 42.9 & 43.4 & 39.6 & 40.4 & 44.9 \\
Romania & n.a. & 10.7 & 25.7 & 24.8 & 21.6 & 26.2 & 33.4 & 32.8 & 32.3 & 32.7 & 31.5 & 31.2 & 31.7 \\
Slovakia & n.a. & n.a. & n.a. & 37.5 & 35.8 & 35.6 & 35.1 & 38.6 & 36.1 & 35.7 & 41.0 & 41.8 & 45.5 \\
Slovenia & n.a. & n.a. & 45,6 & 33.7 & 28.4 & 28.0 & 29.6 & 31.9 & 32.6 & 35.5 & 36.8 & 36.4 & 34.4 \\
Estonia & n.a. & n.a. & 3.3 & 5.1 & 4.7 & 4.5 & 5.0 & 4.3 & 4.5 & 4.0 & 4.0 & 3.0 & 3.0 \\
Latvia & n.a. & n.a. & n.a. & n.a. & 14.2 & 16.2 & 14.5 & 12.0 & 10.4 & 13.1 & 13.3 & 15.0 & 14.9 \\
Lithuania & n.a. & n.a. & n.a. & 14.8 & 15.8 & 19.5 & 23.2 & 19.1 & 22.4 & 28.3 & 28.2 & 26.9 & 24.4 \\
\hline CEECs average & n.a. & 42.7 & 36.0 & 50.9 & 50.0 & 42.8 & 57.6 & 36.6 & 33.7 & 35.4 & 34.6 & 34.2 & 35.3 \\
Euro area average & 61.0 & 61.2 & 65.1 & 69.3 & 71.1 & 75.1 & 77.9 & 78.1 & 77.4 & 75.3 & 73.1 & 72.3 & 72.5 \\
EU average & 58.0 & 58.5 & 63.1 & 68.1 & 69.3 & 73.2 & 75.2 & 74.8 & 74.3 & 71.4 & 68.7 & 67.7 & 67.4 \\
\hline
\end{tabular}

Sources: The Economist Intelligence Unit Country Data, 2002; EBRD Transition Report, 2001; authors' computations 
Table 1. (continued) Maastricht criteria applied to the CEECs

f) Volatility of nominal exchange rates $^{1}(\%)$

\begin{tabular}{lcccccccccccc}
\hline & 1991 & 1992 & 1993 & 1994 & 1995 & 1996 & 1997 & 1998 & 1999 & 2000 & 2001 & 2002 \\
\hline Bulgaria & n.a. & 24.5 & 5.5 & 39.7 & 20.1 & 77.0 & 85.6 & 15.2 & 0.4 & 0.0 & 0.0 & 0.0 \\
Czech Rep. & n.a. & n.a. & n.a. & 1.4 & 1.2 & 1.0 & 4.4 & 4.3 & 2.9 & 2.6 & 2.8 & 5.5 \\
Hungary & 8.0 & 6.2 & 4.4 & 9.6 & 16.0 & 10.3 & 5.8 & 7.9 & 4.3 & 1.8 & 2.3 & 3.4 \\
Poland & 6.9 & 17.3 & 12.6 & 14.5 & 9.5 & 4.9 & 5.7 & 4.7 & 5.4 & 3.7 & 5.6 & 5.1 \\
Romania & 94.7 & 77.5 & 48.5 & 41.7 & 19.2 & 22.1 & 36.9 & 14.8 & 26.7 & 13.2 & 14.8 & 10.1 \\
Slovakia & n.a. & n.a. & n.a. & 3.9 & 1.6 & 0.9 & 1.5 & 3.9 & 6.7 & 2.8 & 1.6 & 1.7 \\
Slovenia & n.a. & n.a. & 14.4 & 8.4 & 2.1 & 5.6 & 3.2 & 2.0 & 2.4 & 3.5 & 3.4 & 2.2 \\
Estonia & n.a. & n.a. & 2.1 & 0.8 & 1.6 & 1.3 & 1.8 & 0.5 & 0.5 & 0.1 & 1.0 & 1.1 \\
Latvia & n.a. & n.a. & 17.1 & 13.8 & 2.5 & 1.3 & 3.4 & 2.0 & 3.8 & 6.4 & 2.6 & 2.5 \\
Lithuania & n.a. & n.a. & n.a. & 10.5 & 6.4 & 2.4 & 6.1 & 3.4 & 4.4 & 8.6 & 4.6 & 2.7 \\
\hline CEECs average & 36.5 & 31.4 & 14.9 & 14.4 & 8.0 & 12.7 & 15.4 & 5.9 & 5.8 & 4.3 & 3.9 & 3.4 \\
US & 5.8 & 5.8 & 6.5 & 3.7 & 5.9 & 2.4 & 6.1 & 3.4 & 4.4 & 8.6 & 4.6 & 4.4 \\
\hline
\end{tabular}

Note:
${ }^{1}$ Standard deviations in percent to average nominal exchange rates to ECU/Euro over two preceding
years
Source:

Table 2. Exchange rate regimes in the CEECs

\begin{tabular}{lccccccccccccc}
\hline & 1990 & 1991 & 1992 & 1993 & 1994 & 1995 & 1996 & 1997 & 1998 & 1999 & 2000 & 2001 & 2002 \\
\hline Bulgaria & 3 & 8 & 8 & 8 & 8 & 8 & 8 & 2 & 2 & 2 & 2 & 2 & 2 \\
Czech Rep. & 3 & 3 & 3 & 3 & 3 & 3 & 6 & 7 & 7 & 7 & 7 & 7 & 7 \\
Hungary & 3 & 3 & 3 & 3 & 3 & 6 & 6 & 6 & 6 & 6 & 6 & 6 & 4 \\
Poland & 3 & 5 & 5 & 5 & 5 & 6 & 6 & 6 & 6 & 6 & 8 & 8 & 8 \\
Romania & 3 & 7 & 7 & 7 & 7 & 7 & 7 & 7 & 7 & 7 & 7 & 7 & 7 \\
Slovakia & 3 & 3 & 3 & 3 & 3 & 3 & 6 & 6 & 7 & 7 & 7 & 7 & 7 \\
Slovenia & n.a & n.a & 7 & 7 & 7 & 7 & 7 & 7 & 7 & 7 & 7 & 7 & 7 \\
Estonia & n.a. & n.a. & 2 & 2 & 2 & 2 & 2 & 2 & 2 & 2 & 2 & 2 & 2 \\
Latvia & n.a & n.a & 8 & 8 & 3 & 3 & 3 & 3 & 3 & 3 & 3 & 3 & 3 \\
Lithuania & n.a & n.a & 8 & 8 & 2 & 2 & 2 & 2 & 2 & 2 & 2 & 2 & 2 \\
\hline
\end{tabular}

Exchange rate regime description:

1: Dollarization, no separate legal tender

2: Currency Board, currency fully backed by foreign exchange reserves

3: Conventional Fixed Pegs, peg to another currency or currency basket within a band of at most $\pm 1 \%$

4: Horizontal Bands, pegs with bands larger than $\pm 1 \%$

5: Crawling Pegs, pegs with central parity periodically adjusted in fixed amounts at a fixed, pre-announced rate or in response to changes in selected quantitative indicators

6: Crawling Bands, crawling pegs combined with bands of more than $\pm 1 \%$

7: Managed Float with No Preannounced Exchange Rate Path, active intervention without precommitment to a preannounced target or path for the exchange rate

8: Independent Float, market-determined exchange rate and monetary policy independent of exchange rate policy.

Sources:

1990 - 2000: Halpern, L. and Wyplosz, C. 2001. "Economic Transformation and Real Exchange Rates in the 2000s: The Balassa-Samuelson Connection." Table 2. Exchange Rate Arrangements.

2001 - 2002: Authors' updates. 
Figure 1

GDP per capita in per cent of German GDP per capita

(based on official exchange rate\$)

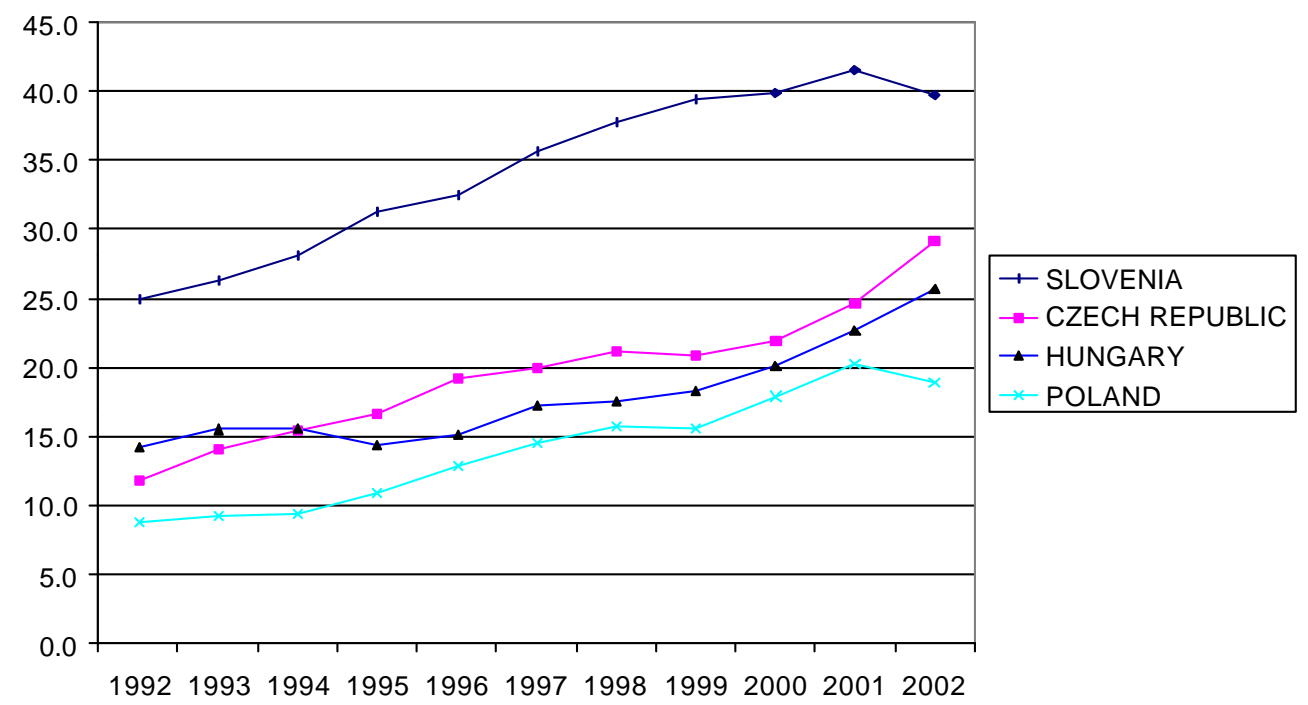

Source: The Economist Intelligence Unit Country Data, 2002; authors' computations

\section{Figure 2}

\section{GDP per capita in per cent of German GDP per capita}

(based on official exchange rate\$)

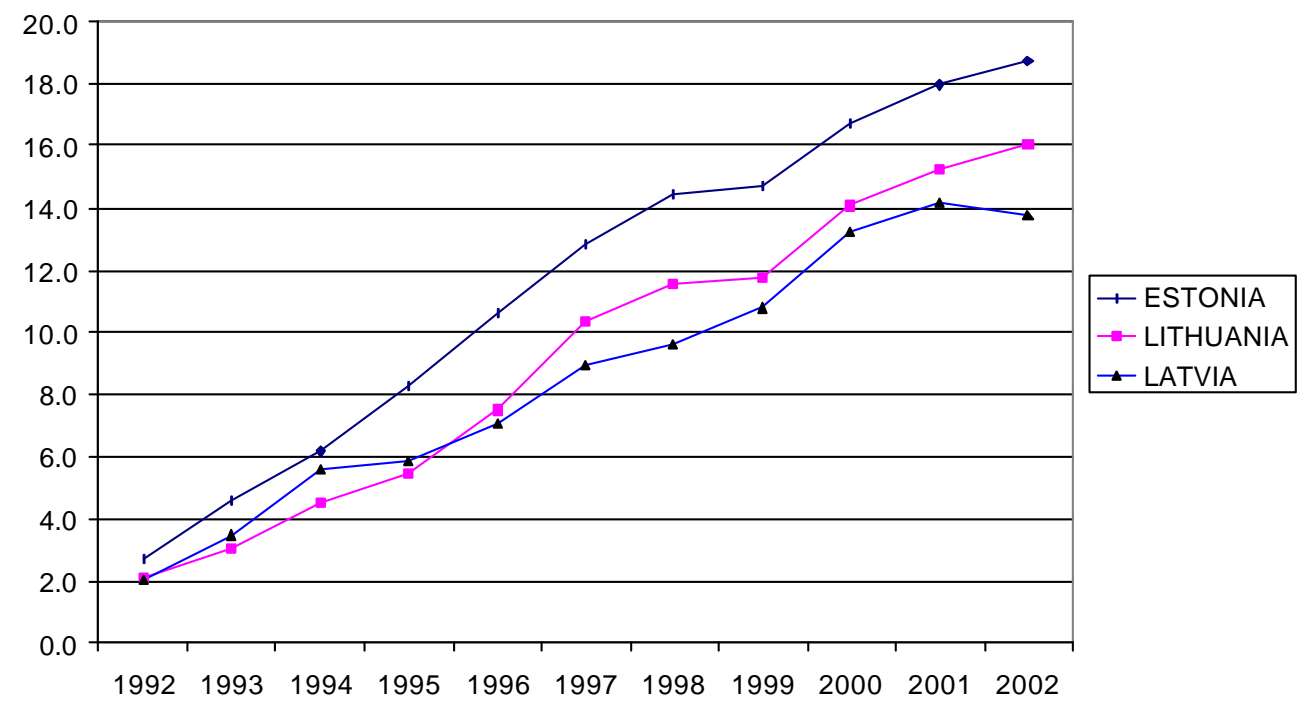

Source: The Economist Intelligence Unit Country Data, 2002; authors' computations 
Figure 3

GDP per capita in per cent of German GDP per capita

(based on official exchange rate\$

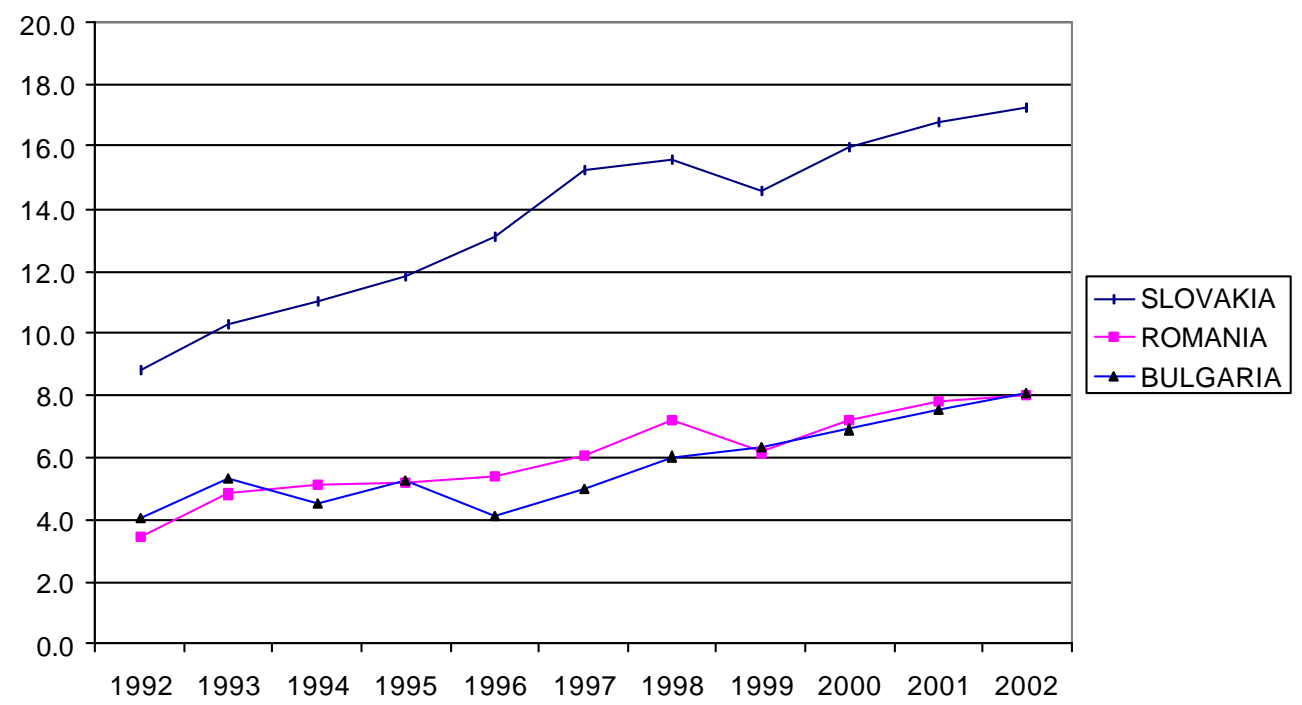

Source: The Economist Intelligence Unit Country Data, 2002; authors' computations

Table 3. Variability of GDP in the CEECs and the EU

\section{Variability across the countries ${ }^{1}$}

\begin{tabular}{ccc}
\hline Year & Across the CEECs, and EU-15 & Across the CEECs and EU-15, excl. Bulgaria and Romania \\
\hline 1992 & & \\
1993 & 0.39 & 0.35 \\
1994 & 0.26 & 0.27 \\
1995 & 0.24 & 0.22 \\
1996 & 0.23 & 0.20 \\
1997 & 0.21 & 0.18 \\
1998 & 0.19 & 0.16 \\
1999 & 0.20 & 0.15 \\
2000 & 0.18 & 0.15 \\
2001 & 0.17 & 0.14 \\
2002 & 0.17 & 0.12 \\
\hline
\end{tabular}

Note: $\quad{ }^{1}$ Variances of $\log ($ GDP per capita), Euro, official rates

Source: The Economist Intelligence Unit Country Data, 2002; authors' computations 
Table 4. Size and degree of openness of the CEECs

\begin{tabular}{|c|c|c|c|c|c|c|}
\hline & \multicolumn{2}{|c|}{ Share of trade in GDP (\%) } & \multicolumn{2}{|c|}{ GDP per capita (US dollars) } & \multicolumn{2}{|c|}{ Population (millions) } \\
\hline & 1992 & 2002 & 1992 & 2002 & 1992 & 2002 \\
\hline Bulgaria & 100 & 106 & 781 & 2,094 & 8.5 & 7.9 \\
\hline Czech Rep. & 108 & 127 & 2,293 & 7,571 & 10.3 & 10.3 \\
\hline Hungary & 63 & 117 & 2,776 & 6,691 & 10.3 & 10.1 \\
\hline Poland & 62 & 71 & 1,695 & 4,890 & 9.9 & 10.1 \\
\hline Romania & 64 & 78 & 662 & 2,084 & 22.8 & 22.4 \\
\hline Slovakia & 140 & 156 & 1,706 & 4,492 & 5.3 & 5.4 \\
\hline Slovenia & 119 & 123 & 4,838 & 10,346 & 2.0 & 2.0 \\
\hline Estonia & 114 & 180 & 523 & 4,869 & 1.5 & 1.4 \\
\hline Latvia & 153 & 103 & 398 & 3,571 & 2.6 & 2.4 \\
\hline Lithuania & 43 & 116 & 400 & 4,178 & 3.7 & 3.5 \\
\hline $\begin{array}{l}\text { CEECs } \\
\text { average }\end{array}$ & 97 & 118 & 1607 & 5079 & 8 & 8 \\
\hline
\end{tabular}

Source: The Economist Intelligence Unit Country Data, 2002; authors' computations

Table 5. Current accounts ( $\%$ of GDP )

\begin{tabular}{lccccccccccc}
\hline & 1992 & 1993 & 1994 & 1995 & 1996 & 1997 & 1998 & 1999 & 2000 & 2001 & 2002 \\
\hline Bulgaria & -4.2 & -10.1 & -0.3 & -1.5 & 1.7 & 10.1 & -0.5 & -5.0 & -5.6 & -6.2 & -4.6 \\
Czech Rep. & n.a. & 1.3 & -1.9 & -2.6 & -7.1 & -6.7 & -2.2 & -2.7 & -5.3 & -4.6 & -3.4 \\
Hungary & 0.9 & -11.0 & -9.8 & -5.7 & -3.7 & -2.2 & -4.9 & -4.4 & -2.9 & -2.1 & -4.3 \\
Poland & -0.2 & 0.3 & -2.5 & -0.1 & -4.8 & -6.1 & -6.9 & -8.5 & -10.3 & -9.0 & -7.9 \\
Romania & -7.7 & -4.7 & -1.5 & -5.0 & -7.3 & -6.1 & -6.9 & -3.6 & -3.7 & -5.9 & -5.2 \\
Slovakia & n.a. & -4.4 & 4.4 & 2.0 & -10.2 & -9.3 & -9.0 & -4.8 & -3.4 & -8.6 & -8.4 \\
Slovenia & 7.4 & 1.5 & 4.0 & -0.5 & 0.2 & 0.1 & -0.7 & -3.9 & -3.4 & -0.4 & -1.2 \\
Estonia & 3.5 & 1.3 & -7.2 & -4.4 & -9.1 & -12.2 & -9.1 & -5.7 & -5.6 & -6.1 & -10.2 \\
Latvia & 14.2 & 19.2 & 5.5 & -0.4 & -5.5 & -6.1 & -10.7 & -9.9 & -6.9 & -9.7 & -9.2 \\
Lithuania & n.a. & -3.2 & -2.2 & -10.2 & -9.2 & -10.2 & -12.1 & -11.2 & -6.0 & -4.8 & -6.1 \\
\hline CEECs & 2.0 & -1.0 & -1.1 & -2.8 & -5.5 & -4.9 & -6.3 & -6.0 & -5.3 & -5.7 & -6.1 \\
average & & & & & & & & & & &
\end{tabular}

Source: The Economist Intelligence Unit Country Data, 2002; authors' computations

Table 6. Chronology of EU Enlargement

\begin{tabular}{|c|c|c|}
\hline Date & $\begin{array}{l}\text { Number of } \\
\text { participant } \\
\text { s }\end{array}$ & Event \\
\hline 1957 & 6 & $\begin{array}{l}\text { Germany, France, Italy, Belgium, Luxembourg and the Netherlands sign the Treaty } \\
\text { establishing the European Economic Community. }\end{array}$ \\
\hline 1973 & 9 & Denmark, Ireland and the United Kingdom join the EEC. \\
\hline 1981 & 10 & Greece joins the EEC. \\
\hline 1986 & 12 & Spain and Portugal join the EEC. \\
\hline 1995 & 15 & Austria, Finland and Sweden join the EU. \\
\hline 1998 & $15+6$ & $\begin{array}{l}\text { EU accession negotiations are started with Cyprus, Hungary, Poland, the Czech } \\
\text { Republic, Slovenia and Estonia }\end{array}$ \\
\hline 2000 & $15+12$ & $\begin{array}{l}\text { EU accession negotiations are started with Bulgaria, Romania, Slovakia, Latvia, } \\
\text { Lithuania, and Malta. }\end{array}$ \\
\hline 2002 & $15+12$ & $\begin{array}{l}\text { Cyprus, the Czech Republic, Estonia, Hungary, Latvia, Lithuania, Malta, Poland, } \\
\text { Slovakia, and Slovenia are invited to join the EU on } 1 \text { May 2004; The accession } \\
\text { of Bulgaria and Romania is tentatively set for } 1 \text { January } 2007 .\end{array}$ \\
\hline
\end{tabular}

Sources: http://www.mic.org.mt/Malta-EU/chronology.htm; http://www.euroobserver.com 


\section{Annex A}

Table A. Convergence of Ireland, Portugal, and Spain to the European Union as opposed to the United States

(a) Supply shocks, yearly

\begin{tabular}{ll|ccc|ccc}
\hline Period & & \multicolumn{3}{|c|}{ Coefficient a } & \multicolumn{3}{c}{ Coefficient b } \\
\hline \multirow{2}{*}{$1970-2002$} & Mean & Ireland & Portugal & Spain & Ireland & Portugal & Spain \\
& St Dev & $(0.04)$ & -0.01 & 0.00 & 0.47 & 0.46 & 0.51 \\
$1994-2002$ & Mean & -0.04 & -0.03 & $(0.03)$ & $(0.09)$ & $(0.19)$ & $(0.06)$ \\
& St Dev & $(0.03)$ & $(0.01)$ & -0.02 & 0.42 & 0.34 & 0.45 \\
& & \multicolumn{1}{|c|}{$(0.01)$} & $(0.01)$ & $(0.01)$ & $(0.00)$ \\
\hline
\end{tabular}

(b) Supply shocks, quarterly

\begin{tabular}{lc|ccc|ccc}
\hline Period & & \multicolumn{3}{|c|}{ Coefficient a } & \multicolumn{3}{c}{ Coefficient b } \\
\hline \multirow{2}{*}{$1970-2002$} & Mean & Ireland & Portugal & Spain & Ireland & Portugal & Spain \\
& St Dev & $(0.02)$ & 0.00 & 0.00 & 0.42 & 0.45 & 0.51 \\
$1994-2002$ & Mean & -0.01 & -0.01 & $(0.02)$ & $(0.02)$ & $(0.09)$ & $(0.02)$ \\
& St Dev & $(0.01)$ & $(0.00)$ & $(0.00)$ & $(0.01)$ & $(0.02)$ & $(0.00)$ \\
\multicolumn{1}{c}{$\begin{array}{c}\text { Prior to EU } \\
\text { accession }\end{array}$} & & & & & & \\
Mean & 0.02 & 0.02 & 0.02 & 0.42 & 0.37 & 0.50 \\
St Dev & $(0.02)$ & $(0.02)$ & $(0.01)$ & $(0.02)$ & $(0.03)$ & $(0.02)$ \\
\hline
\end{tabular}

Note : ${ }^{1)} 1970-1972$ for Ireland; 1977-1985 for Portugal and Spain

(c) Demand shocks, yearly

\begin{tabular}{ll|ccc|ccc}
\hline Period & & \multicolumn{3}{|c|}{ Coefficient a } & \multicolumn{3}{c}{ Coefficient b } \\
\hline \multirow{2}{*}{$1970-2002$} & Mean & Ireland & Portugal & Spain & Ireland & Portugal & Spain \\
& St Dev & $(0.04$ & -0.02 & 0.03 & 0.39 & 0.37 & 0.44 \\
$1994-2002$ & $(0.02)$ & $(0.02)$ & $(0.06)$ & $(0.03)$ & $(0.04)$ \\
& Mean & -0.05 & 0.00 & 0.02 & 0.45 & 0.35 & 0.42 \\
& St Dev & $(0.02)$ & $(0.01)$ & $(0.01)$ & $(0.02)$ & $(0.00)$ & $(0.00)$ \\
\hline
\end{tabular}

(d) Demand shocks, quarterly

\begin{tabular}{ll|ccc|ccc}
\hline Period & & \multicolumn{3}{|c|}{ Coefficient a } & \multicolumn{3}{c}{ Coefficient b } \\
\hline \multirow{2}{*}{$1970-2002$} & Mean & Ireland & Portugal & Spain & Ireland & Portugal & Spain \\
& St Dev & $(0.01)$ & 0.00 & -0.01 & 0.43 & 0.37 & 0.50 \\
$1994-2002$ & Mean & 0.01 & $0.01)$ & $(0.01)$ & $(0.02)$ & $(0.03)$ & $(0.02)$ \\
& St Dev & $(0.01)$ & $(0.00)$ & -0.01 & 0.45 & 0.35 & 0.49 \\
\multicolumn{2}{c}{$\begin{array}{c}\text { Prior to EU } \\
\text { accession }\end{array}$} & & & & & & $(0.00)$ \\
Mean & 0.02 & 0.00 & 0.00 & $0.00)$ & \\
& St Dev & $(0.01)$ & $(0.01)$ & $(0.01)$ & $(0.01)$ & 0.38 & 0.50 \\
\hline
\end{tabular}

Note : ${ }^{1)} 1970-1972$ for Ireland; 1977-1985 for Portugal and Spain 
Figure A. Convergence of Ireland, Portugal, and Spain to the European Union as opposed to the United States, 1970-2002

(a) Supply shocks, coefficients b(t)

Yearly
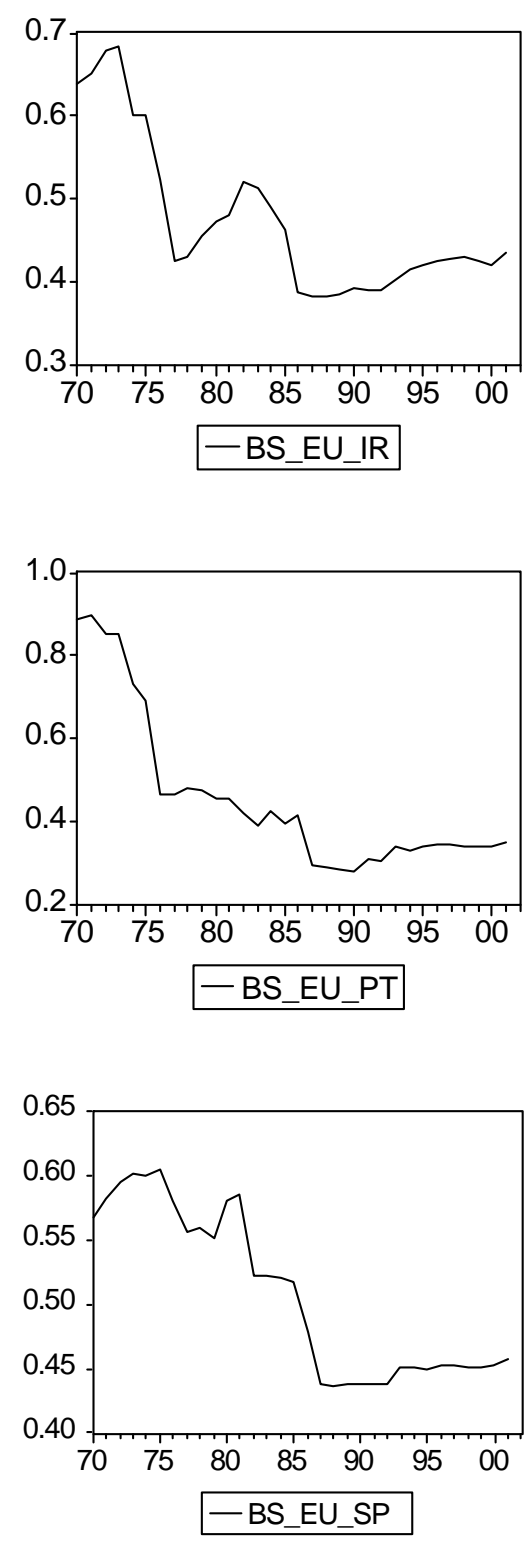

Quarterly

Ireland

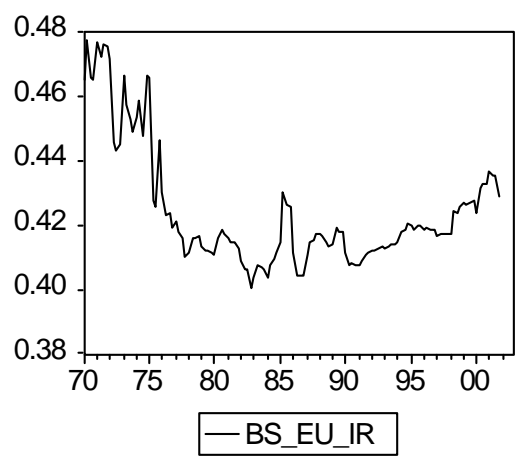

Portugal

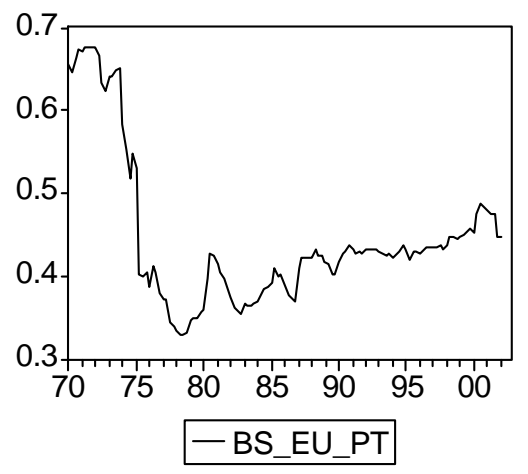

Spain

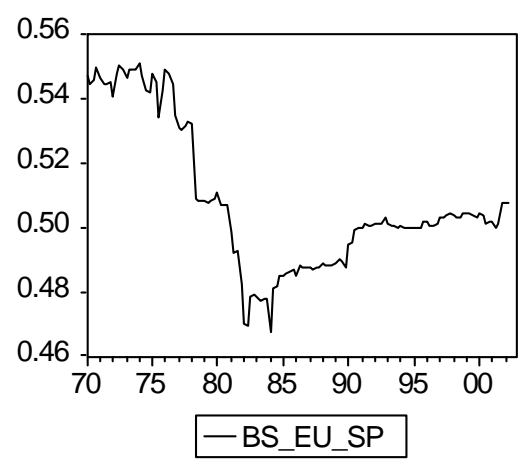


Figure A (continued). Convergence of Ireland, Portugal, and Spain to the European Union as opposed to the United States, 1970-2002

(b) Demand shocks, coefficients b(t)

Yearly
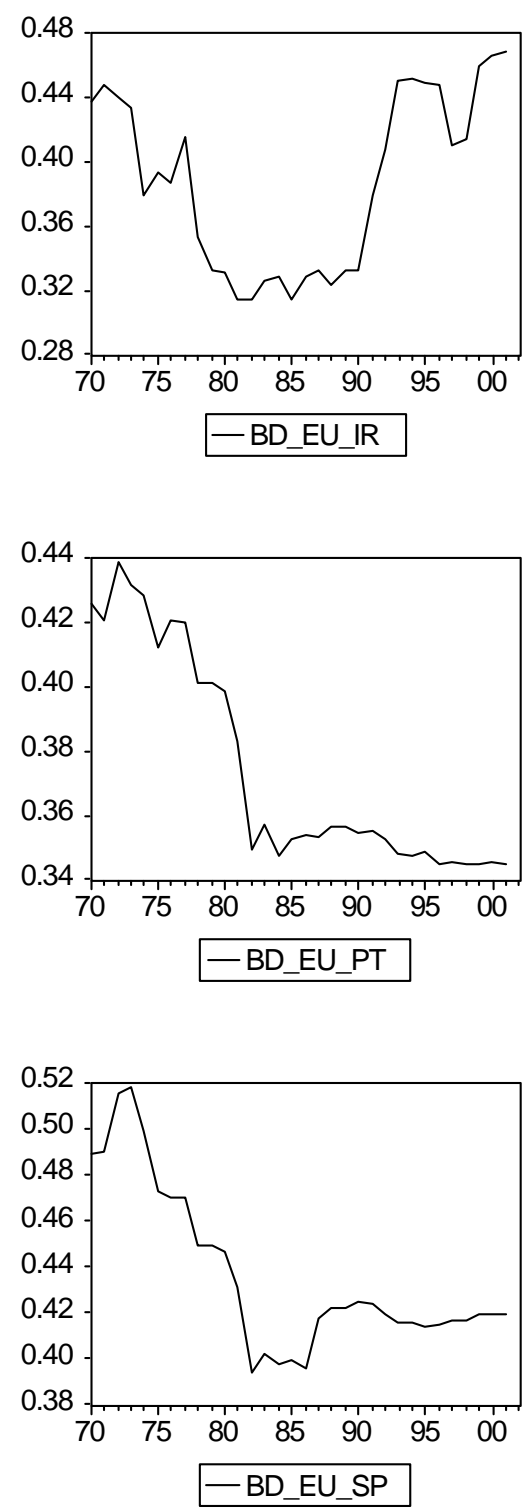

Quarterly

Ireland

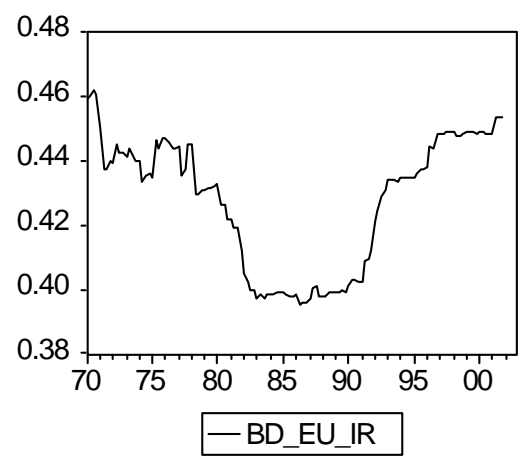

\section{Portugal}

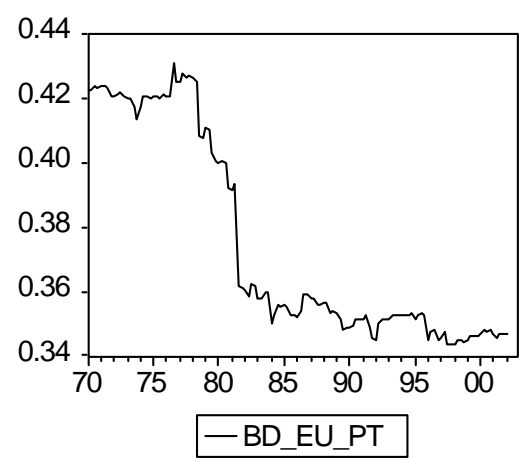

Spain

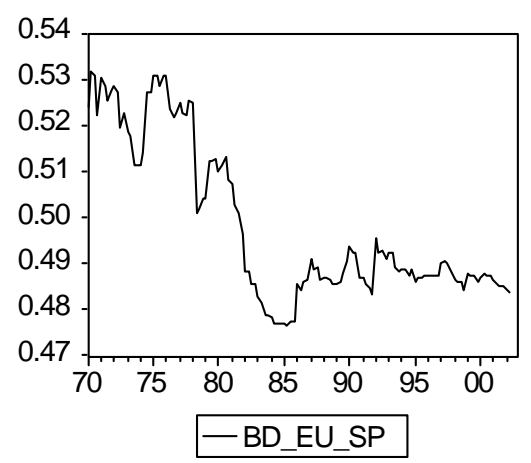




\section{Annex B}

Table B. Convergence of the CEECs towards the European Union as opposed to the United States, 1994-2002

(a) Supply shocks

\begin{tabular}{lcccccccc}
\hline & Czech Rep & Estonia & Hungary & Latvia & Poland & Romania & Slovakia & Slovenia \\
\hline Mean & -0.07 & 0.16 & 0.10 & 0.07 & 0.04 & -0.09 & 0.15 & -0.08 \\
St Dev & $(0.38)$ & $(0.08)$ & $(0.09)$ & $(0.10)$ & $(0.09)$ & $(0.20)$ & $(0.16)$ & $(0.29)$ \\
& & & & Coef b & & & & \\
Mean & $0.01^{1)}$ & 0.72 & $0.39^{2)}$ & $0.34^{1)}$ & $-0.02^{1)}$ & $0.13^{1)}$ & $0.30^{1)}$ & 0.55 \\
St Dev & $(0.28)$ & $(0.20)$ & $(0.14)$ & $(0.14)$ & $(0.26)$ & $(0.13)$ & $(0.28)$ & $(0.37)$ \\
\hline
\end{tabular}

(b) Demand shocks

\begin{tabular}{lcccccccc}
\hline & Czech Rep & Estonia & Hungary & Latvia & Poland & Romania & Slovakia & Slovenia \\
\hline Mean & 0.10 & 0.14 & 0.07 & 0.05 & 0.02 & 0.15 & 0.24 & 0.07 \\
St Dev & $(0.15)$ & $(0.29)$ & $(0.10)$ & $\begin{array}{c}(0.26) \\
\text { Coef b }\end{array}$ & $(0.22)$ & $(0.41)$ & $(0.32)$ & $(0.22)$ \\
Mean & $0.49^{4)}$ & $0.36^{3)}$ & $0.35^{3)}$ & $0.35^{3)}$ & $0.50^{4)}$ & 0.89 & 0.59 & 0.78 \\
St Dev & $(0.11)$ & $(0.10)$ & $(0.04)$ & $(0.16)$ & $(0.19)$ & $(0.42)$ & $(0.09)$ & $(0.09)$ \\
\hline
\end{tabular}

Notes. The superscripts denote a comparison with the corresponding values of Ireland, Portugal and Spain prior to their EU entry (estimated over 1970-1972 for Ireland, and 1977-1985 for Portugal and Spain) :

1) : inferior to Portuguese supply shocks coefficient $b(t)$ (equal to 0.37 )

${ }^{2)}$ : inferior to Irish supply shocks coefficient $b(t)$ (equal to 0.42 )

3) : inferior to Portuguese demand shocks coefficient $b(t)$ (equal to 0.38 )

${ }^{4)}$ : not exceeding Spanish demand shocks coefficient b(t) (equal to 0.50) 
Figure B. Convergence of the CEECs towards the European Union as opposed to the United States, 1994-2002

(a) Supply shocks, coefficients b(t)

Czech Republic

Hungary

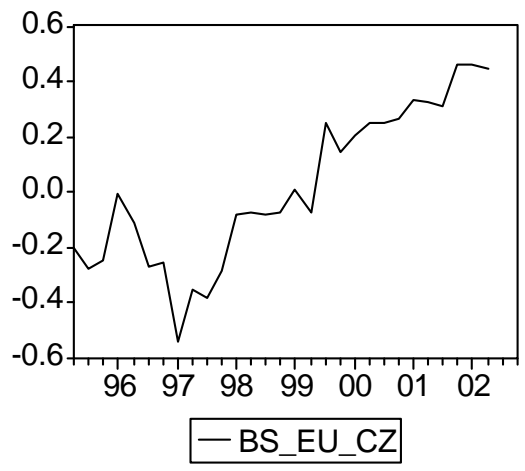

Poland

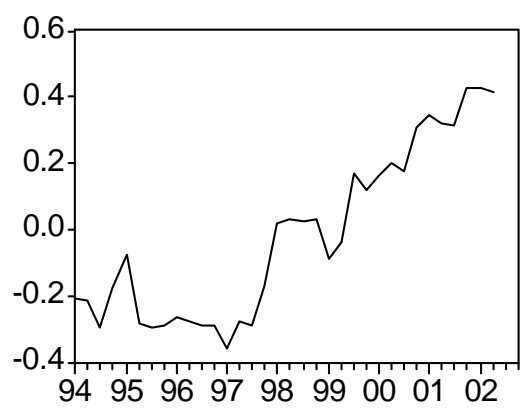

-BS_EU_PO

Slovakia

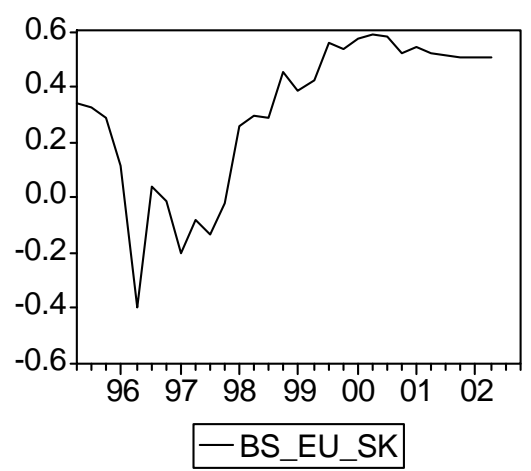

Estonia

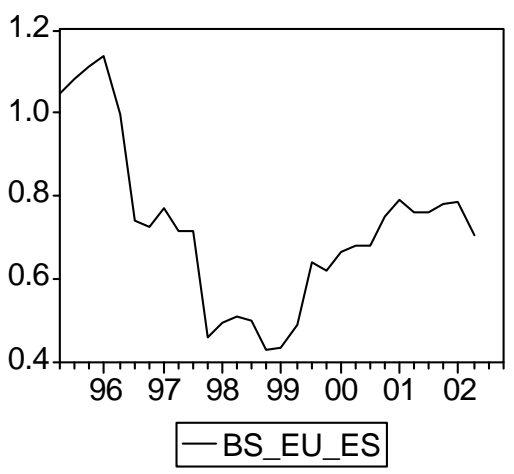

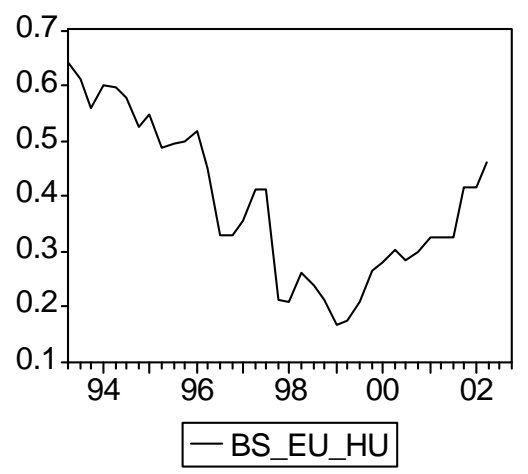

Romania

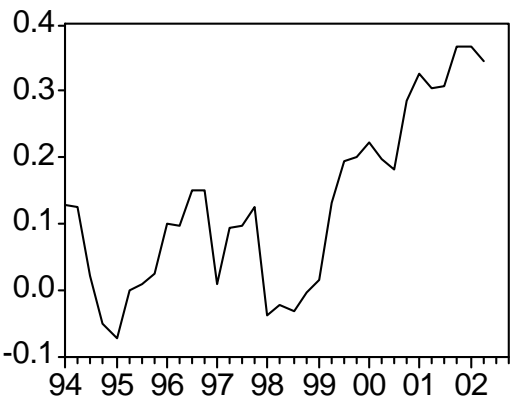

-BS_EU_RO

Slovenia

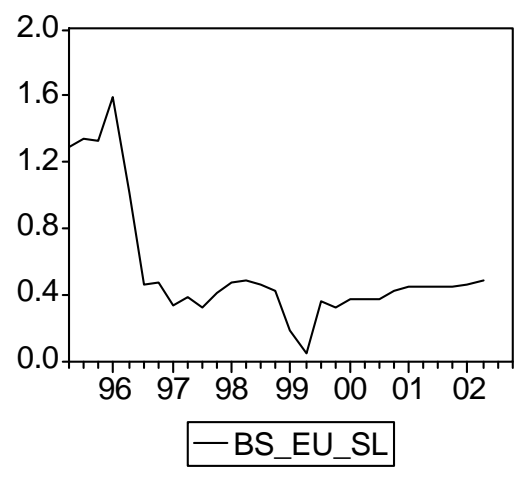

Latvia

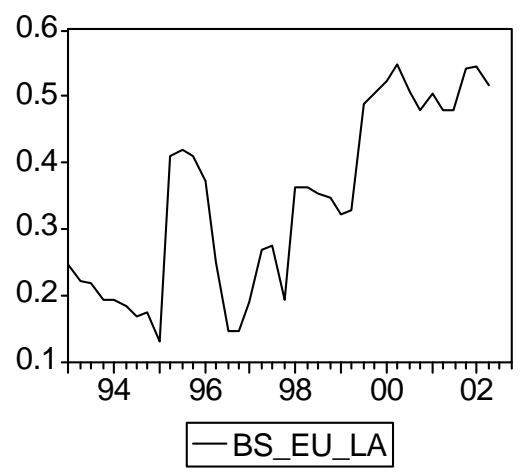


Figure B (continued). Convergence of the CEECs towards the European Union as opposed to the United states, 1994-2002

(b) Demand shocks, coefficients b(t)

Czech Republic

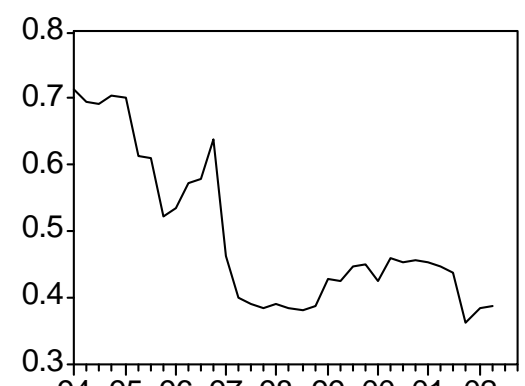

949596979899000102

-BD_EU_CZ

Poland

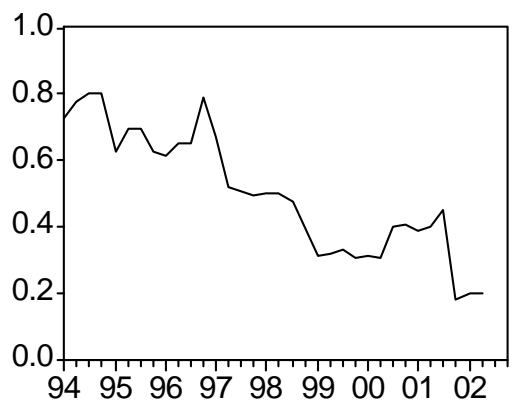

-BD_EU_PO

Slovakia

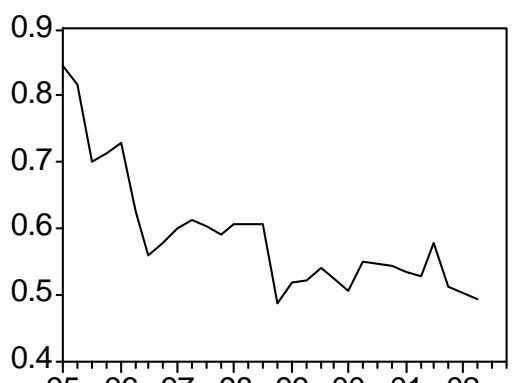

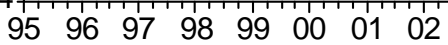

-BD_EU_SK

Estonia

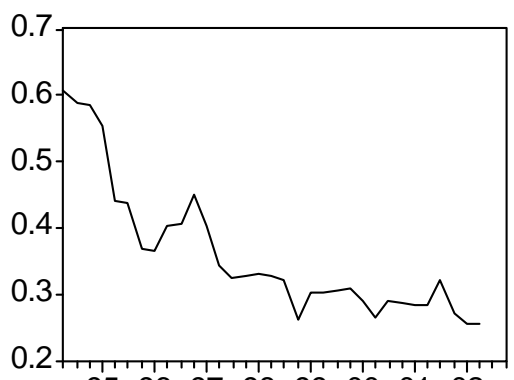

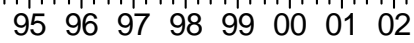

-BD_EU_ES
Hungary

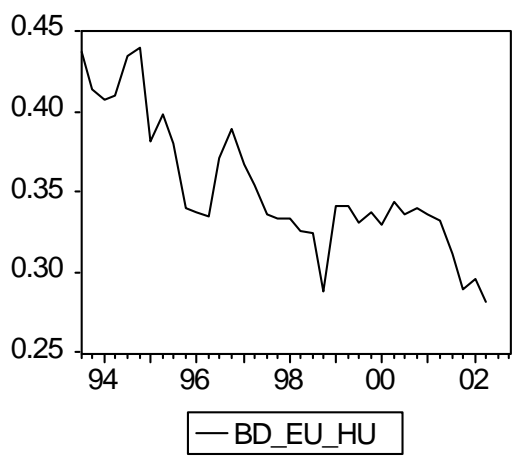

Romania
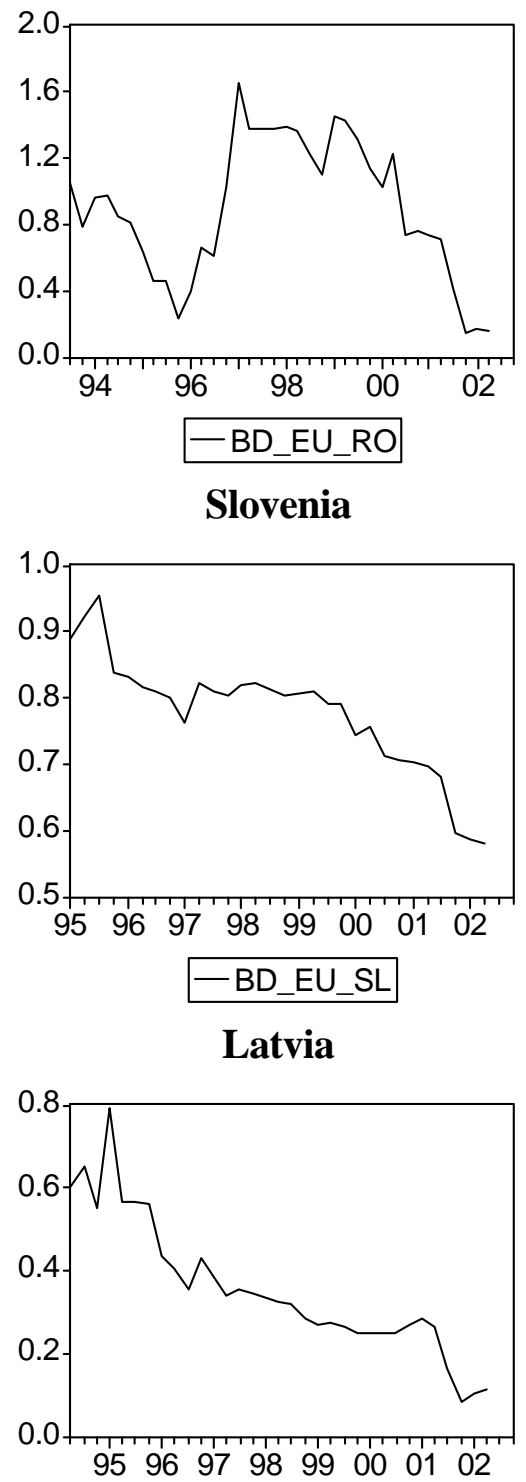

-BD_EU_LA 
CERGE-EI

P.O.BOX 882 Politických vezòù 7

11121 Prague 1

Czech Republic http://www.cerge-ei.cz 